\title{
Box-modelling of the impacts of atmospheric nitrogen deposition and benthic remineralisation on the nitrogen cycle of the eastern tropical South Pacific
}

\author{
Bei Su, Markus Pahlow, and Andreas Oschlies \\ GEOMAR Helmholtz-Zentrum für Ozeanforschung Kiel, Marine Biogeochemical Modelling, Düsternbrooker Weg 20, \\ 24105 Kiel, Germany
}

Correspondence to: Bei Su (bsu@geomar.de)

Received: 25 April 2015 - Published in Biogeosciences Discuss.: 2 September 2015

Revised: 21 June 2016 - Accepted: 14 July 2016 - Published: 9 September 2016

\begin{abstract}
Both atmospheric deposition and benthic remineralisation influence the marine nitrogen cycle, and hence ultimately also marine primary production. The biological and biogeochemical relations in the eastern tropical South $\mathrm{Pa}$ cific (ETSP) among nitrogen deposition, benthic denitrification and phosphorus regeneration are analysed in a prognostic box model of the oxygen, nitrogen and phosphorus cycles in the ETSP. Atmospheric nitrogen deposition $(\approx$ $1.5 \mathrm{Tg} \mathrm{Nyr}^{-1}$ for the years 2000-2009) is offset by half in the model by reduced $\mathrm{N}_{2}$ fixation, with the other half transported out of the model domain. Model- and data-based benthic denitrification in our model domain are responsible for losses of 0.19 and $1.0 \mathrm{Tg} \mathrm{Nyr}^{-1}$, respectively, and both trigger nitrogen fixation, partly compensating for the $\mathrm{NO}_{3}^{-}$loss. Modeland data-based estimates of enhanced phosphate release via sedimentary phosphorus regeneration under suboxic conditions are 0.062 and $0.11 \mathrm{TgPyr}^{-1}$, respectively. Since phosphate is the ultimate limiting nutrient in the model, even very small additional phosphate inputs stimulate primary production and subsequent export production and $\mathrm{NO}_{3}^{-}$loss in the oxygen minimum zone (OMZ). A sensitivity analysis of the local response to both atmospheric deposition and benthic remineralisation indicates dominant stabilising feedbacks in the ETSP, which tend to keep a balanced nitrogen inventory; i.e. nitrogen input by atmospheric deposition is counteracted by decreasing nitrogen fixation; $\mathrm{NO}_{3}^{-}$loss via benthic denitrification is partly compensated for by increased nitrogen fixation; enhanced nitrogen fixation stimulated by phosphate regeneration is partly counteracted by stronger water-column denitrification. Even though the water column in our model
\end{abstract}

domain acts as a $\mathrm{NO}_{3}^{-}$source, the ETSP including benthic denitrification might be a $\mathrm{NO}_{3}^{-}$sink.

\section{Introduction}

Marine primary production (PP) by phytoplankton is a key factor controlling the strength of the oceanic biological carbon pump and the amount of $\mathrm{CO}_{2}$ that is stored in the ocean (Gruber, 2004; Okin et al., 2011). PP is controlled by light and nutrients, such as nitrogen, phosphorus or iron, necessary for the production of phytoplankton. These nutrients are supplied to the light-lit surface waters by upwelling, turbulent entrainment of subsurface water, riverine inputs, biological nitrogen fixation, atmospheric deposition and benthic remineralisation (Falkowski et al., 1998; Kasai et al., 2002; Duce et al., 2008; Bakun and Weeks, 2008; Moore and Braucher, 2008).

Nitrogen is often the limiting nutrient for phytoplankton in the ocean (Moore et al., 2013). On the other hand, oceanic nitrogen is thought to adjust, via nitrogen gain and loss processes, to the marine phosphorus inventory on geological timescales, making phosphorus the ultimate limiting nutrient and nitrogen the proximate limiting nutrient (Tyrrell, 1999). The ocean's nitrogen inventory has a turnover time of a few thousand years, being affected by relatively large interacting nitrogen sinks and sources. The exact mechanisms and timescales of the interactions are not well understood. Estimates of oceanic nitrogen fixation, the main fixed-N source 

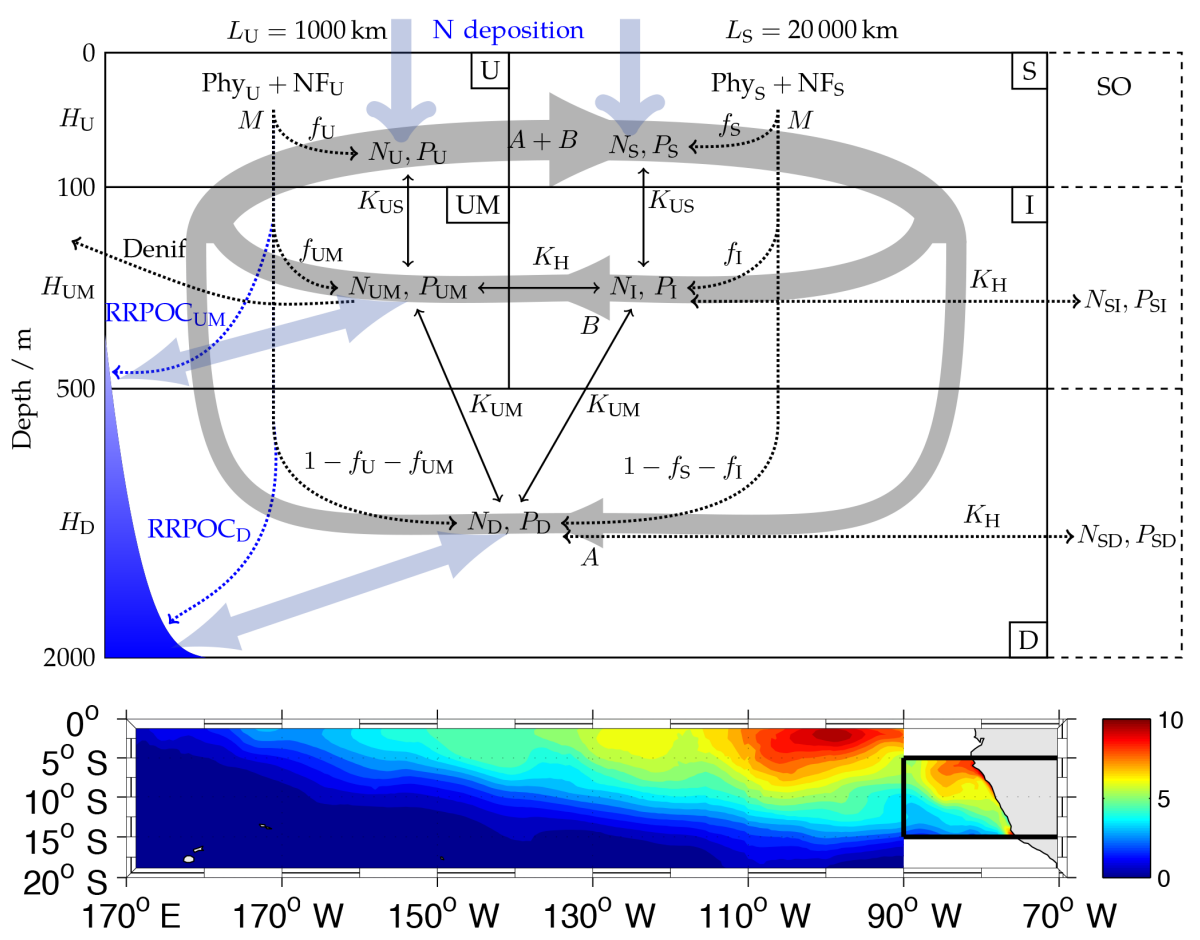

Figure 1. Model structure. The model domain comprises five boxes representing the top $100 \mathrm{~m}$ of an upwelling region (U), the underlying oxygen minimum zone (UM), and an adjacent open-ocean basin divided into a surface (S) and an intermediate-depth box (I). A deep box (D) underlies both the upwelling region and the open ocean. The large-scale circulation is represented by deep (A) and shallow (B) convection (thick grey lines). Mixing between boxes is implemented via mixing coefficients $(K)$. Remineralisation derived from primary production by ordinary (Phy) and diazotrophic (NF) phytoplankton in the surface boxes consumes oxygen. Under anoxic conditions remineralisation is fuelled by anaerobic remineralisation (Denif). In the configuration employed in this study, the model domain exchanges nutrients and oxygen with the Southern Ocean (right, denoted as "SO"). Nitrogen deposition and benthic remineralisation are included additionally to represent their influence on the local water-column nutrient concentrations (thick light blue arrows). The graph above is a schematic figure of our model domain; the graph below shows the surface of our model domain, and the colour bar is nitrate concentration in $\mu$ mol $\mathrm{L}^{-1}$.

into the ocean, vary from 106 to $330 \mathrm{Tg} \mathrm{Nyr}^{-1}$ based on both in situ observations and models (Codispoti et al., 2001; Brandes and Devol, 2002; Gruber and Sarmiento, 2002; Gruber, 2004; Großkopf et al., 2012). Water-column denitrification and anaerobic ammonium oxidation (anammox) in oxygen minimum zones (OMZs), accounting for $100-300 \mathrm{Tg} \mathrm{Nyr}^{-1}$, and benthic denitrification, estimated as $95-300 \mathrm{Tg} \mathrm{Nyr}^{-1}$, mainly determine the oceanic fixed-N sink (Gruber and Sarmiento, 2002; Gruber, 2004; Codispoti, 2007; Bohlen et al., 2012; Eugster and Gruber, 2012; DeVries et al., 2012). Due to the large uncertainties in the major sources and sinks of the global nitrogen cycle, the balance of the nitrogen inventory in the ocean is still a matter of debate (Gruber, 2004; Codispoti, 2007; DeVries et al., 2012).

Phosphate can be the ultimate limiting nutrient on geological timescales even in regions with fixed-nitrogen deficits with respect to the Redfield equivalent of the phosphate concentration (Tyrrell, 1999; Su et al., 2015; Auguéres and Loreau, 2015). The ocean's phosphorus budget has been suggested to be unbalanced in the modern ocean with sedimentary burial as the major sink exceeding phosphorus sources
(Wallmann, 2010). This condition might be alleviated by benthic phosphorus regeneration, which can be enhanced under low-oxygen bottom waters $\left(\mathrm{O}_{2}<20 \mu \mathrm{mol} \mathrm{L}^{-1}\right)$ (Slomp and Van Cappellen, 2007; Wallmann, 2010; Noffke et al., 2012). Input of bioavailable phosphorus into the ocean stimulates primary production, and decomposition of subsequent export production enhances $\mathrm{O}_{2}$ consumption in the ocean, in turn increasing the volume of oceanic oxygen-deficit water and the fixed-N loss. Consequently, phosphorus regeneration is expected to be enhanced by enlarging OMZs, possibly leading to a positive feedback loop (Van Cappellen and Ingall, 1994; Wallmann, 2003).

Iron (Fe) limitation has been suggested to exert some control on both primary production and $\mathrm{N}_{2}$ fixation in the eastern tropical South Pacific (ETSP) (Dekaezemacker et al., 2013), possibly related to relatively low rates of atmospheric $\mathrm{Fe}$ deposition in this area in comparison to the eastern tropical North Atlantic (Mills et al., 2004; Moore et al., 2009). However, ambient Fe concentrations are relatively high, allowing complete utilisation of phosphate in the upwelling region of the ETSP (Dekaezemacker et al., 2013). Also, the 
stimulation of $\mathrm{N}_{2}$ fixation due to $\mathrm{Fe}$ enrichment reported by Dekaezemacker et al. (2013) appears positively related to ambient $\mathrm{Fe}$ concentration. This is counter to what would be expected if $\mathrm{N}_{2}$ fixation was mainly $\mathrm{Fe}$ limited. Thus, the role of Fe limitation in the ETSP remains unclear, and we have excluded Fe dynamics from this work, which also facilitates focusing on the influence of benthic nitrogen and phosphate remineralisation in the ETSP.

OMZs also play an important role in the global marine fixed-N budget as they are responsible for a large fraction of total marine fixed-N loss (Canfield, 2006). The relative contribution of heterotrophic denitrification and autotrophic anammox to the total oceanic fixed-nitrogen sink remains debated (Lam et al., 2009; Ward et al., 2009). Anammox has been observed to be a major fixed-N loss process in the ETSP (Lam et al., 2009; Kalvelage et al., 2013). However, the essential substrates for anammox are ultimately provided by heterotrophic processes (Koeve and Kähler, 2010; Kalvelage et al., 2013), such as organic-matter remineralisation or dissimilatory nitrate reduction to ammonium (DNRA). Thus, both denitrification and anammox are driven by the flux of organic matter into the OMZ. For simplicity, heterotrophic denitrification is considered to be the major fixed-N loss process in the present study. Continental shelves and the upper continental slopes are the most important sites for benthic fixed-N loss (Christensen et al., 1987; Devol, 1991). However, Bohlen et al. (2011) found that the continental shelf and upper continental slope of the ETSP across a section at $11^{\circ} \mathrm{S}$ are sites of nitrogen recycling rather than fixed-N loss because of relatively low rates of denitrification and high rates of $\mathrm{NH}_{4}^{+}$release from DNRA. This illustrates that the $\mathrm{NH}_{4}^{+}$ released from DNRA should be taken into account when the benthic fixed-N sink is estimated.

In the last few decades, a number of model- and databased investigations have been carried out on the importance of atmospheric fixed-N input into the ocean for marine biogeochemical cycles (Duce, 1986; Duce et al., 1991; Krishnamurthy et al., 2007, 2010; Okin et al., 2011; MouriñoCarballido et al., 2012; Kim et al., 2014). Duce et al. (2008) suggest that anthropogenic nitrogen deposition is rapidly approaching estimates for global oceanic $\mathrm{N}_{2}$ fixation, while preindustrial deposition was an order of magnitude lower. However, the response of nitrogen fixation and denitrification to atmospheric nitrogen deposition remains an open question. Atmospheric nitrogen inputs into the global ocean are dominated by inorganic nitrogen from anthropogenic sources (Warneck, 1988; Paerl and Whitall, 1999). The exact magnitude of organic nitrogen deposition and its bioavailability are still under appraisement due to a lack of enough observations (Duce et al., 2008; Zamora et al., 2011). Therefore, we apply the finding of Cornell et al. (2003) and Kanakidou et al. (2012) that DON accounts for $30 \%$ of total nitrogen deposition in our model and investigate its role on the nitrogen budget of the ETSP with the bioavailability measured by Paerl and Whitall (1999). Several scenarios with differ- ent DON bioavailability are assessed to analyse uncertainties regarding the bioavailability of DON.

Various biogeochemical models have addressed the effects and feedbacks between the major sources and sinks in the marine nitrogen cycle (Van Cappellen and Ingall, 1994; Deutsch et al., 2001, 2007; Krishnamurthy et al., 2007; Somes et al., 2013; Landolfi et al., 2013). However, most of them have explored only a subset of the atmospheric, pelagic and benthic nitrogen sources and sinks. Using a conceptually simple and computationally efficient box model, we here attempt a synthesis considering all essential sources and sinks and their mutual interactions, with the only exception of riverine input, which is excluded from our model analysis because it contributes negligibly to the nitrogen inventory in the ETSP (Seitzinger and Kroeze, 1998).

\section{Model description}

\subsection{Circulation and biogeochemical model}

The circulation model is the same as in $\mathrm{Su}$ et al. (2015), which is a prognostic five-box model to explore the interactions among oceanic circulation, nitrogen fixation and watercolumn denitrification in the OMZ of the ETSP. Briefly, the physical parameters were calibrated to fit the average $\delta^{14} \mathrm{C}$ (Key et al., 2004) of each box and biogeochemical parameters are constrained by literature data. $\delta^{14} \mathrm{C}$ is the ${ }^{13} \mathrm{C}$ fractionation-corrected ratio of ${ }^{14} \mathrm{C} /{ }^{12} \mathrm{C}$, which is commonly used in ocean modelling to evaluate and calibrate model physics because it tends to cancel the effect of the biotic downward transport of ${ }^{14} \mathrm{C}$ with the rain of organic particles produced by marine organisms. All the simulations in this manuscript employ the Open-boundary + Reduceddenitrification (OBRD) configuration of $\mathrm{Su}$ et al. (2015), which allows for the exchange of deep and intermediate ETSP waters with the Southern Ocean ("SO" in Fig. 1) and applies reduced remineralisation rates under suboxic conditions. The model domain consists of five boxes representing the water column of an upwelling region and an adjacent ocean basin. The $\mathrm{U}$ box represents the upper upwelling region. The UM box is the OMZ below, where suboxia is expected to develop. The $\mathrm{S}$ box represents the surface ocean away from the upwelling zone. Below the $\mathrm{S}$ box sits the I box, which represents water of intermediate depth and exchanges water with UM. D is the deep box, which represents water deeper than $500 \mathrm{~m}$ (model configuration shown in Fig. 1).

We represent two phytoplankton types in the biogeochemical model: ordinary phytoplankton (Phy) and nitrogen fixers (NF) as defined in Su et al. (2015). Both Phy and NF concentrations are determined by the steady-state balance between net primary production (NPP) and mortality (M), respectively, in the $\mathrm{U}$ and $\mathrm{S}$ boxes. Phy requires both phosphate and nitrate, and growth of Phy is described by a Blackman-type dependence on the nitrate and phosphate limitation terms. NF 
can fix $\mathrm{N}_{2}$ as long as $\mathrm{PO}_{4}^{3-}$ is available. A quadratic mortality term is adopted for both Phy and NF, considering possible viral lysis, phytoplankton aggregation or a feedback between zooplankton grazing and phytoplankton concentration. $\mathrm{N}_{2}$ fixers are given a lower maximum growth rate, which is one third of the maximum growth rate of ordinary phytoplankton, in order to account for the high cost of nitrogen fixation (La Roche and Breitbarth, 2005).

Dead phytoplankton is immediately remineralised in the surface layer and underlying boxes according to the predefined remineralisation fractions. Remineralisation occurs preferentially via aerobic respiration, with anaerobic denitrification and the associated nitrogen loss setting in only when all $\mathrm{O}_{2}$ has been consumed by aerobic respiration. When oxygen is exhausted in the OMZ, remineralisation is assumed to slow down by a factor of 5 , and accordingly denitrification within the UM box is responsible for one fifth of the remaining organic-matter remineralisation, and the remainder will be remineralised in the $\mathrm{D}$ box.

In order to represent the nitrogen and phosphate fluxes across the water-sediment interface, remineralisation of particulate organic carbon reaching the sediment (POC rain rate, RRPOC) is included additionally in the UM and D boxes. RRPOC is calculated according to the method introduced in Sect. 2.4, and we assume that all the POC is buried in the sediment.

\subsection{Model configurations}

The above descriptions define the control configuration. In order to investigate the model sensitivity to atmospheric nitrogen deposition and benthic remineralisation, we employ another nine model configurations incorporating either a subset or all of these processes, which are summarised in Table 1.

In the NDEP configuration, atmospheric nitrogen input into the surface ocean according to the estimate by Lamarque et al. (2011) is included; MBD and DBD are configurations in which model- and data-based benthic denitrification rates are included in the control configuration; MPR and DPR represent configurations with model- and data-based benthic phosphorus regeneration, respectively. Detailed information of all processes is presented in Sects. 2.3, 2.4 and 2.5; the configuration names are summarised in Table 1.

Nitrogen deposition, benthic denitrification and phosphate regeneration are integrated into the synthesis model configurations to explore the model sensitivity to each process and their mutual interactions in the ETSP. Synthesis configuration Syn1 includes model-based benthic denitrification and phosphorus regeneration; Syn2 includes the data-based benthic denitrification and phosphorus regeneration; Syn3 includes atmospheric deposition in addition to the processes in Syn1; Syn4 includes atmospheric deposition in addition to the processes in Syn2. The synthesis configurations Syn1 to Syn 4 are summarised in Table 1.

\subsection{Atmospheric nitrogen deposition}

Years 2000-2009 levels of dry and wet inorganic nitrogen deposition following the RCP 4.5 scenario (Lamarque et al., 2011) are examined in our work. Inferred atmospheric inorganic nitrogen deposition rates are 0.081 and $1.4 \mathrm{Tg} \mathrm{Nyr}^{-1}$ (73.1 and $64.9 \mathrm{mg} \mathrm{Nm}^{-2} \mathrm{yr}^{-1}$ ) for the $\mathrm{U}$ and $\mathrm{S}$ box, respectively. Note that the circulation remains constant in our model, and only atmospheric nitrogen deposition fluxes are included as an additional annual nitrogen input into the surface (U and $\mathrm{S})$ boxes.

Atmospheric phosphorus deposition is excluded from our analysis because its amount is much smaller than the Redfield equivalent of nitrogen atmospheric deposition (Duce et al., 1991). This results in $\mathrm{N} / \mathrm{P}$ (mole / mole) ratios of more than 100 , much higher than the average elemental $\mathrm{N} / \mathrm{P}$ ratio required by phytoplankton (Duce et al., 2008; Mahowald et al., 2008).

\subsection{Benthic denitrification}

The empirical transfer function of Bohlen et al. (2012) is applied to predict benthic inorganic nitrogen loss $\left(L_{\text {DIN }}\right.$ in $\mu \mathrm{molN} \mathrm{m}{ }^{-2} \mathrm{~d}^{-1}$ ) through benthic denitrification, which can account for the net loss of dissolved inorganic nitrogen (DIN) from the sediment.

$L_{\mathrm{DIN}}=\left(0.06+0.19 \cdot 0.99^{\left(\mathrm{O}_{2}-\mathrm{NO}_{3}^{-}\right)_{\mathrm{bw}}}\right) \cdot \mathrm{RRPOC}$,

where $\mathrm{NO}_{3}^{-}$and $\mathrm{O}_{2}$ are bottom-water nitrate and oxygen concentrations in $\mu \mathrm{mol} \mathrm{kg}{ }^{-1}$, and the RRPOC is in $\mu \mathrm{molC}{ }^{-2} \mathrm{~d}^{-1}$. Since the bottom-water $\mathrm{NO}_{3}^{-}$and $\mathrm{O}_{2}$ concentrations are well known in the ETSP, the uncertainty in our estimation of benthic denitrification comes mostly from uncertainties in the rain rate, which, in turn, depends on biological production, as a function of phytoplankton biomass and its physiological status. Simulated phytoplankton concentrations in the surface boxes of the model roughly agree with estimates by Behrenfeld et al. (2005) from Aqua-MODIS satellite data and the Redfield $\mathrm{C}: \mathrm{N}$ ratio (U box: $1.06 \mu \mathrm{mol} \mathrm{N} \mathrm{kg}{ }^{-1}$ simulated vs. $0.68 \mu \mathrm{mol} \mathrm{N} \mathrm{kg}{ }^{-1}$ from Aqua-MODIS; S Box: $0.23 \mu \mathrm{molN} \mathrm{kg}{ }^{-1}$ simulated vs. $0.28 \mu \mathrm{mol} \mathrm{N} \mathrm{kg}^{-1}$ from Aqua-MODIS).

\subsubsection{Model-based estimation of benthic denitrification}

Fixed-N losses via benthic denitrification $\left(L_{\mathrm{DIN}}\right)$ in the UM and $\mathrm{D}$ boxes are obtained according to Eq. (1), with the respective simulated actual $\mathrm{NO}_{3}^{-}$and $\mathrm{O}_{2}$ concentrations taken as the bottom-water concentrations, and RRPOC is estimated from the export production from of the $\mathrm{U}$ and $\mathrm{S}$ boxes $\left(\mathrm{EP}_{\mathrm{U}}\right.$ and $\mathrm{EP}_{\mathrm{S}}$ ) and the Martin curve (Eq. 2) (Martin et al., 1987):

$\mathrm{RRPOC}=F \cdot\left(\frac{z}{100}\right)^{-b}$,

where RRPOC is the rain rate, $F$ is the export production from both surface boxes and $z$ is the water 
Table 1. Summary of model configurations including different processes. Process abbreviations are "N-DEP", "Model BD", "Data BD", "Model PR" and "Data PR". N-DEP represents the atmospheric nitrogen input into the surface ocean according to the estimate by Lamarque et al. (2011); Model BD and Data BD represent model- and data-based benthic denitrification, respectively; Model PR and Data PR are model- and data-based benthic phosphorus regeneration, respectively.

\begin{tabular}{|c|c|c|c|c|c|}
\hline \multirow{2}{*}{ Configuration } & \multicolumn{5}{|c|}{ Processes } \\
\hline & $\mathrm{N}-\mathrm{DEP}$ & Model BD & Data BD & Model PR & Data PR \\
\hline \multicolumn{6}{|l|}{ Control } \\
\hline NDEP & + & & & & \\
\hline MBD & & + & & & \\
\hline MPR & & & & + & \\
\hline DBD & & & + & & \\
\hline DPR & & & & & + \\
\hline \multicolumn{6}{|l|}{ Synthesis configurations } \\
\hline MBD+MPR (Syn1) & & + & & + & \\
\hline DBD+DPR (Syn2) & & & + & & + \\
\hline MBD+MPR+NDEP (Syn3) & + & + & & + & \\
\hline DBD+DPR+NDEP (Syn4) & + & & + & & + \\
\hline
\end{tabular}

+ Indicates that the process is included.

depth. The bathymetry of the regions of the UM and D boxes is derived from the 2-minute gridded global relief dataset ETOPO2 (http://www.ngdc.noaa.gov/mgg/gdas/gd_ designagrid.html). We apply $b=0.82$ in Eq. (2), which is the global average according to Berelson (2001) and also close to his estimate for the ETSP. An exponent of 0.4 for Eq. (2) in suboxic water is implied by Van Mooy et al. (2002). Therefore, sensitivity experiments are performed with $b=0.4$. From Eq. (2) and the fraction of the lower boundary of the respective box in contact with the seafloor, the RRPOC at the sediment surfaces of the UM and D boxes is calculated according to Eqs. (3) and (4):

$\mathrm{RRPOC}_{\mathrm{UM}}=\mathrm{EP}_{\mathrm{U}} \cdot \mathrm{SD}_{\mathrm{UM}} \cdot \mathrm{AMC}_{\mathrm{UM}}$,

$\mathrm{RRPOC}_{\mathrm{D}}=\left(\mathrm{EP}_{\mathrm{U}}+\mathrm{EP}_{\mathrm{S}}\right) \cdot \mathrm{SD}_{\mathrm{D}} \cdot \mathrm{AMC}_{\mathrm{D}}$,

where $\mathrm{EP}_{\mathrm{U}}$ and $\mathrm{EP}_{\mathrm{U}}+\mathrm{EP}_{\mathrm{S}}$ represent the export production $(\mathrm{F}$ in Eq. 2) in the upwelling region and the whole model domain, respectively; $\mathrm{AMC}_{\mathrm{UM}}$ and $\mathrm{AMC}_{\mathrm{D}}\left(\left(\frac{z}{100}\right)^{-b}\right.$ in Eq. 2) are the average Martin curve values corresponding to the actual water depth $(z)$ in the ETOPO2 data; $\mathrm{SD}_{\mathrm{UM}}$ and $\mathrm{SD}_{\mathrm{D}}$ represent the percentages in contact with the sediment in the $\mathrm{UM}$ and $\mathrm{D}$ boxes, respectively (Table 2 ).

\subsubsection{Data-based estimation of benthic denitrification}

For a second and independent estimate of $L_{\mathrm{DIN}}$, we combine observations from different datasets. $\mathrm{O}_{2}$ and $\mathrm{NO}_{3}^{-}$concentrations for our model domain are obtained from the annual objectively analysed mean concentrations of the WOA 2009 $1^{\circ} \times 1^{\circ}$ data (Garcia et al., 2010a, b) and interpolated over the region of our model domain to match the resolutions of the other datasets.
RRPOC is estimated from primary production following Bohlen et al. (2012). According to the carbon-based approach of Behrenfeld et al. (2005), average annual primary production is derived from photosynthetically available radiation (PAR), the diffuse attenuation coefficient at $490 \mathrm{~nm}$ (K490), chlorophyll $a(\mathrm{Chl} a)$ and mixed layer depth (MLD). PAR, K490 and Chl $a$ are from the AquaMODIS satellite data (2005-2010) (http://oceancolor.gsfc. nasa.gov/), and MLD is from the Hybrid Coordinate Ocean Model (HYCOM, http://orca.science.oregonstate.edu/1080. by.2160.monthly.hdf.mld.hycom.php). Export production is estimated from primary production and sea-surface temperature (SST) (Dunne et al., 2005), where SST is from the WOA 2009 annual average $1^{\circ} \times 1^{\circ}$ temperature data (Locarnini et al., 2010). The rate of particle transport at each grid cell to the seafloor is calculated using the Martin curve (Eq. 2) (Martin et al., 1987). To obtain more accurate estimates for RRPOC of our regional box model, all data processed in this experiment are interpolated on a grid of $2^{\prime} \times 2^{\prime}$ in the UM box and $20^{\prime} \times 20^{\prime}$ in the D box, and the ETOPO2 data $\left(2^{\prime} \times 2^{\prime}\right)$ are averaged within each $20^{\prime} \times 20^{\prime}$ grid cell in the $\mathrm{D}$ box. The Aqua-MODIS data $\left(5^{\prime} \times 5^{\prime}\right)$ and $\mathrm{NO}_{3}^{-}$and $\mathrm{O}_{2}$ concentrations from WOA 2009 dataset are interpolated or averaged horizontally to match these resolutions. The vertical resolution of the $\mathrm{NO}_{3}^{-}$and $\mathrm{O}_{2}$ concentrations are interpolated to resolve the bathymetry of the ETOPO2 data, and the $\mathrm{NO}_{3}^{-}$and $\mathrm{O}_{2}$ concentrations closest to the sediment are applied in Eq. (1) for the bottom-water $\mathrm{NO}_{3}^{-}$and $\mathrm{O}_{2}$ concentrations.

Finally, the $L_{\text {DIN }}$ derived from observational datasets is averaged over the regions represented by $\mathrm{UM}$ and $\mathrm{D}$ boxes to produce an annual $\mathrm{NO}_{3}^{-}$loss term. 


\subsection{Phosphorus regeneration}

Phosphorus regeneration is estimated according to Wallmann (2010) and Flögel et al. (2011), with both model- and databased estimates for the rain rate. We estimate benthic $\mathrm{PO}_{4}^{3-}$ regeneration (resupply of benthic $\mathrm{PO}_{4}^{3-}$ to the water column, $\left.\mathrm{Ben}_{\mathrm{DP}}\right)$ from the RRPOC degradation ratio $\left(r_{\mathrm{REG}}\right)$ and the POC burial rate in the sediments (BURPOC) according to

Ben $_{\text {DPUM }}=\frac{\text { RRPOC }_{U M}-\text { BURPOC }_{U M}}{r_{\text {REG }}}$,
Ben $_{\text {DPD }}=\min \left(\frac{\text { RRPOC }_{\mathrm{D}}-\text { BURPOC }_{D}}{r_{\text {REG }}}, \frac{\text { RRPOC }}{106}\right)$,

where RRPOC is estimated with the methods described in Sections. 2.4.1 and 2.4.2. A minimum condition is introduced in the $\mathrm{D}$ box to prevent $\mathrm{Ben}_{\mathrm{DP}}$ exceeding the rain rate of particulate organic phosphate $(\mathrm{RRPOP}=\mathrm{RRPOC} / 106)$ to the deep ocean but not for the UM box because there are possible extra sources of RRPOP, such as inputs via weathering or eolian deposition, for the continental shelf, which is contained in the UM box in our model.

BURPOC is estimated from Eq. (7) for the continental shelf (UM box) and Eq. (8) for the deep-sea sediment (D box), and $r_{\mathrm{REG}}$ is the $\mathrm{C}: \mathrm{P}$ regeneration ratio estimated via Eq. (9) following the empirical relations of Wallmann (2010).

$$
\begin{aligned}
& \text { BURPOC }_{\mathrm{UM}}=0.14 \cdot \mathrm{RRPOC}_{\mathrm{UM}}^{1.11}, \\
& \text { BURPOC }_{\mathrm{D}}=0.014 \cdot \operatorname{RRPOC}_{\mathrm{D}}^{1.05}, \\
& r_{\mathrm{REG}}=123+(-112) \cdot \exp \left(-\frac{\mathrm{O}_{2}}{32}\right),
\end{aligned}
$$

where $\mathrm{O}_{2}$ is the oxygen concentration in the ambient bottom water (in $\mu \mathrm{mol} \mathrm{kg}^{-1}$ ). $r_{\mathrm{REG}}$ in Eq. (9) is higher than the Redfield ratio in oxic water, resulting in preferential $P$ burial under oxic conditions; $r_{\mathrm{REG}}$ is much smaller than the Redfield ratio when $\mathrm{O}_{2}<20 \mu \mathrm{mol} \mathrm{kg}{ }^{-1}$, indicating excess phosphate release from the sediment under suboxic conditions.

\subsection{Model sensitivity experiments}

Since the atmospheric nitrogen deposition data from Lamarque et al. (2011) only include results of a single chemistryclimate model, a multi-model perspective could offer additional insights into the influence of uncertainties in nitrogen deposition on our model results. Three recent inter-model comparisons (Dentener et al., 2006; Lamarque et al., 2013; Vet et al., 2014) show very similar performance over our model domain; therefore, we choose the results from Dentener et al. (2006), which is also applied in a number of benchmark papers such as Duce et al. (2008). The influence of DON from the atmospheric nitrogen deposition on the nitrogen budget is investigated by applying the fact that DON accounts for $30 \%$ of the total dissolved nitrogen deposition suggested by Cornell et al. (2003) and Kanakidou et al. (2012). The bioavailability of the deposited DON is also considered by assuming that $30 \%$ of it is available to primary producers according to Paerl and Whitall (1999). In addition, 10 and $50 \%$ bioavailability is also applied in our model to account for the underlying uncertainties. Considering the rapid rise of nitrogen deposition (Duce et al., 2008), we also apply the RCP 8.5 scenario for the year 2100 predicted by Lamarque et al. (2011) in our model domain.

Bonnet et al. (2013) reported a large quantity of aphotic nitrogen fixation in the ETSP, which can account for as much as $90 \%$ of the total fixed-N input via nitrogen fixation there. To test the effect of aphotic nitrogen fixation on the nitrogen budget of the ETSP, we include the aphotic nitrogen fixation rate measured by Bonnet et al. (2013) as additional $\mathrm{NO}_{3}^{-}$input in two sensitivity experiments: AphoticNfix 1 and AphoticNfix2. Due to the very low sampling density of their data, we extrapolate their data to our model domain and assume that the nitrogen fixation rate in the open ocean is the same as that measured at the coast. Aphotic nitrogen fixation is responsible for $0.0711,0.0528$ and $0.0528 \mu \mathrm{mol} \mathrm{N} \mathrm{kg}^{-1} \mathrm{yr}^{-1}\left(0.44,6.5\right.$ and $\left.25.6 \mathrm{Tg} \mathrm{N} \mathrm{yr}^{-1}\right)$ fixed-N input into the UM, I and D boxes, respectively, with estimates from the 2010 cruise (AphoticNfix1). It contributes $0.0109,0.0057$ and $0.0059 \mu \mathrm{molN} \mathrm{kg}^{-1} \mathrm{yr}^{-1}(0.067$, 0.70 and $2.9 \mathrm{Tg} \mathrm{Nyr}^{-1}$ ) when applying estimates for the 2011 cruise (AphoticNfix2).

Since our model domain only includes the top $2000 \mathrm{~m}$ of the water column, the sediments only account for a small portion of the whole sediment of the ETSP (Table. 2). A sensitivity experiment "high-BD/PR" is performed with the assumption that all of the bottom of the $\mathrm{D}$ box is in contact with the sediment below $500 \mathrm{~m}$ (high benthic denitrification (high$\mathrm{BD})$, or high phosphorus regeneration (high-PR)) including all $\mathrm{NO}_{3}^{-}$losses by benthic denitrification and phosphate release by phosphorus regeneration in the sediment.

The original work of Martin et al. (1987) and Van Mooy et al. (2002) indicates a lower value for the exponent $b$ of Eq. (2) in suboxic water. We perform an additional sensitivity experiment with $b=0.4$ according to the suggestion by Van Mooy et al. (2002) to explore the influence of benthic denitrification and phosphorus regeneration under conditions of slower POC remineralisation.

We perform another sensitivity experiment to explore the influence of organic-matter remineralisation on the benthic denitrification and phosphorus regeneration with more recent findings (Guidi et al., 2015), where we apply the variable Martin curve exponent $b$ values in our model domain. In the UM box, $b=0.83$, which corresponds to the PeruChile upwelling region, is applied, whereas $b=0.85$ is applied in the $\mathrm{D}$ box, which is the average of the $b$ values for the regions named Chile-Peru Current Coastal (CHIL), Pacific Equatorial Divergence (PEQD), South Pacific Subtropical Gyre (SPSG) and Western Pacific Warm Pool (WARM) in Guidi et al. (2015). 
Table 2. Summary of data-based flux estimates. "N deposition" is the annual nitrogen input via atmospheric deposition; "Sediment percentage" is the percentage of the surface areas of the UM and D boxes in contact with the sediment; "Average Martin curve fraction" represents the average fractions (calculated from the Martin curve) of export production reaching the sediment for each grid point of the topography data; "NPP" is the net primary production estimated from Aqua-MODIS satellite data; "Data BD" and "Data PR" represent fixed-N loss via benthic denitrification and phosphate release via phosphorus regeneration in the UM and D boxes, respectively. High-BD indicates that the full sediment of the $\mathrm{D}$ box is included to estimate $\mathrm{NO}_{3}^{-}$loss via benthic denitrification and phosphate release via phosphorus regeneration.

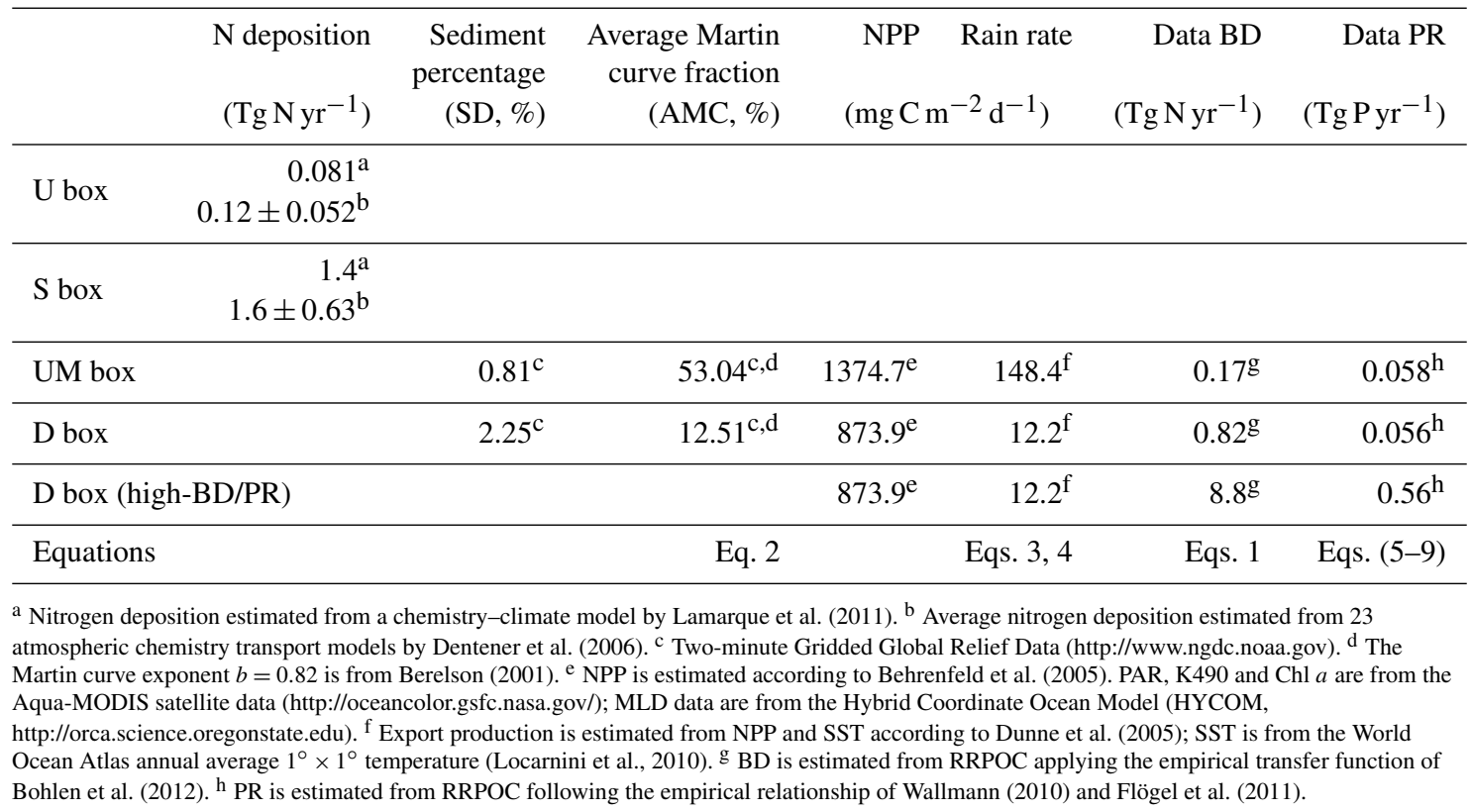

\section{Results}

\subsection{Nitrogen deposition}

Due to the low $\mathrm{NO}_{3}^{-}$concentrations in the surface $\mathrm{U}$ and $\mathrm{S}$ boxes, the annual nitrogen input by atmospheric nitrogen deposition accounts for 63 and $10 \%$, respectively, of nitrogen inventories of the $\mathrm{U}$ and $\mathrm{S}$ boxes.

Figure 2 indicates that the extra bioavailable nitrogen input by nitrogen deposition reduces the growth of nitrogen fixers in the surface ocean mainly in the U box, even though more nitrogen is deposited in the $\mathrm{S}$ box. Nitrogen fixation is reduced by about 0.7 and $0.1 \mathrm{Tg} \mathrm{Nyr}^{-1}$, respectively, in the $\mathrm{U}$ and $\mathrm{S}$ boxes (about 18 and $5 \%$ of the total). The reduction in nitrogen fixation accounts for about $48 \%$ of the total bioavailable nitrogen inputs into surface waters from atmospheric deposition $\left(1.5 \mathrm{Tg} \mathrm{Nyr}^{-1}\right)$.

Water-column denitrification stays almost unchanged because the increase in export production (EP) by Phy (ordinary phytoplankton) is almost exactly compensated for by the decrease in $\mathrm{EP}$ of $\mathrm{NF}$, resulting in essentially unchanged total EP. As a result of the $\approx 50 \%$ of the nitrogen deposition not compensated for by lower nitrogen fixation, the model domain becomes a larger fixed-N source (Fig. 2). The fixed-N loss through the lateral boundary increases from $0.93 \mathrm{Tg} \mathrm{Nyr}^{-1}$ in the control configuration to $1.7 \mathrm{Tg} \mathrm{Nyr}^{-1}$ in the configurations including nitrogen deposition, leading

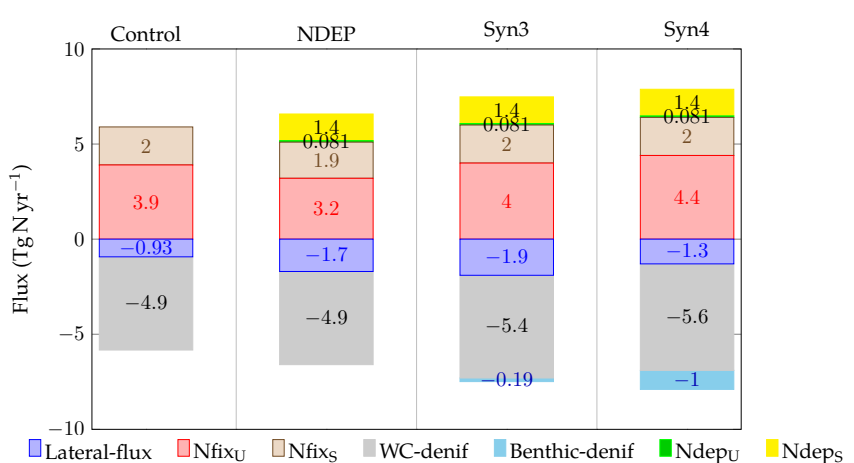

Figure 2. Nitrogen fluxes after including atmospheric nitrogen deposition in the control, Syn3 and Syn 4 configurations defined in Table 1. Lateral-flux is the nitrogen efflux or influx through the southern boundary; $\mathrm{Nfix}_{U}$ and $\mathrm{Nfix}_{\mathrm{S}}$ represent the nitrogen fixation rate by NF, respectively, in the $\mathrm{U}$ and $\mathrm{S}$ boxes; WC-denif is water-column denitrification; NdepU and $\mathrm{Ndep}_{S}$ are the nitrogen input into surface $\mathrm{U}$ and $\mathrm{S}$ boxes via nitrogen deposition.

to about $0.78 \mathrm{Tg} \mathrm{Nyr}^{-1}$ extra fixed-N loss from the model domain, i.e. about $50 \%$ of the total bioavailable nitrogen input from atmospheric deposition. Thus, almost all the extra nitrogen input into the model domain via nitrogen deposition is offset by reduced nitrogen fixation and enhanced lateral transport out of the model domain. 
Nitrogen deposition has no significant influence on biogeochemical tracer concentrations of the model in steady state: Phy concentration increases by $3 \%$ in the $U$ box and even smaller changes occur in the S box, which can be attributed to the stronger nitrogen deficit in the region above the OMZ (U box) than in the open ocean (S box) (Fig. S2 in Supplement). The largest effect is a decrease by about $9 \%$ of the concentration of NF in the U box, partly counteracting the nitrogen input via nitrogen deposition (Fig. 3). NF concentration stays almost unaltered in the $\mathrm{S}$ box (Fig. 3). Slight variations of the $\mathrm{NO}_{3}^{-}$concentration occur in the $\mathrm{UM}$ box and of $\mathrm{O}_{2}$ concentrations in the $\mathrm{I}$ and $\mathrm{D}$ boxes (Fig. S2).

\subsection{Benthic denitrification}

The data-derived benthic denitrification and phosphorus regeneration in the UM and D boxes are shown in Table 2 . Modelled NPP in the surface ocean above the UM and D boxes is, respectively, 1.4 and $0.87 \mathrm{~g} \mathrm{C} \mathrm{m}^{-2} \mathrm{day}^{-1}$, indicating higher NPP in the coastal upwelling region and lower NPP in the open ocean adjacent to the upwelling region, which is consistent with the estimate by Behrenfeld et al. (2005). Due to the small sediment-area percentages, the annual nitrogen loss by benthic denitrification is 0.17 and $0.82 \mathrm{Tg} \mathrm{Nyr}^{-1}$ in the UM and D boxes, accounting for only about $0.14 \%$ and $5.1 \times 10^{-3} \% \mathrm{yr}^{-1}$, respectively, of the $\mathrm{NO}_{3}^{-}$inventories in these boxes (Table 2). The higher sedimentary $\mathrm{NO}_{3}^{-}$sink in the UM box can be attributed to the anoxic conditions and larger RRPOC.

Our simulated biogeochemical tracer concentrations in steady state are quite robust with respect to benthic denitrification (Fig. 3). Including benthic denitrification causes only minor deviations in the MBD and DBD configurations compared to the control run. Nitrogen fixation rates increase by about 2.9 and $5.8 \%$, respectively, in the MBD and DBD configurations (A bars in panels MBD and DBD of Fig. 4). Most of this increase occurs in the $\mathrm{U}$ box, which receives water with a strong $\mathrm{N}$ deficit via upwelling.

Obviously, the response is stronger in the DBD configuration than in the MBD configuration because fixed-N loss via benthic denitrification in the DBD configuration is approximately 5 times larger (A bars in Fig. 4). The DBD configuration results in a stronger responses of nitrogen fixation and lateral fluxes to benthic denitrification: the increase in nitrogen fixation cannot fully compensate for the nitrogen loss by benthic denitrification. Thus, the model domain becomes a smaller fixed-N source, about $25 \%$ of that in the control configuration. In other respects, the steady-state solutions of the MBD and DBD configurations are almost identical to those of the control configuration after including benthic denitrification (Fig. S3). The temporal development of biogeochemical tracer concentrations is also insensitive to the presence or absence of benthic denitrification (Fig. S3).

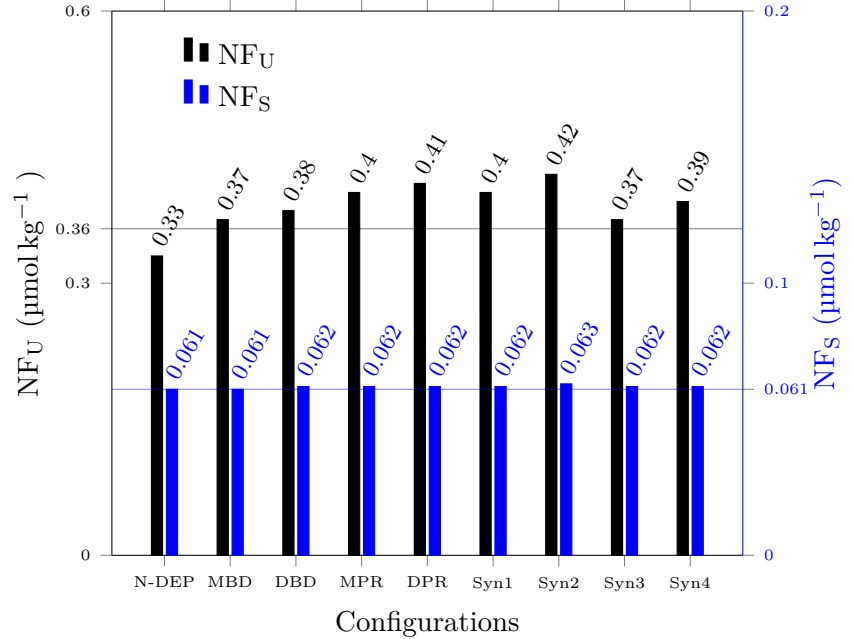

Figure 3. Sensitivity of simulated steady-state concentrations of nitrogen fixers $\mathrm{NF}_{\mathrm{U}}$ and $\mathrm{NF}_{\mathrm{S}}$ in the $\mathrm{U}$ and $\mathrm{S}$ boxes, respectively. Horizontal grey and light blue lines represent the $\mathrm{NF}_{\mathrm{U}}$ and $\mathrm{NF}_{\mathrm{S}}$ concentrations in the control configuration, respectively. Syn1, Syn2, Syn3 and Syn4 denote the "MBD + MPR", "DBD + DPR", "MBD + MPR + NDEP", and "DBD + DPR + NDEP" synthesis configurations defined in Table 1.

\subsection{Phosphorus regeneration}

Phosphate release by phosphorus regeneration accounts for about $0.23 \%$ and $2.2 \times 10^{-3} \% \mathrm{yr}^{-1}$, respectively, of the total phosphate inventories in the UM and D boxes (Table 2). The higher sedimentary $\mathrm{PO}_{4}^{3-}$ source in the $\mathrm{UM}$ box can be attributed to the anoxic conditions and larger RRPOC. The phosphate release associated with benthic phosphorus regeneration can stimulate nitrogen fixation and EP from the surface ocean, followed by higher water-column denitrification, owing to enhanced decomposition of exported organic matter (A bars in MPR and DPR panels in Fig. 4). In the MPR configuration, nitrogen fixation increases by about $18 \%$ in the $\mathrm{U}$ box and stays almost unchanged in the $\mathrm{S}$ box. In the DPR configuration, nitrogen fixation also increases by about $23 \%$ in the $U$ box when benthic phosphate release is included (Fig. 4). Water-column denitrification increases by 10 and $14 \%$, respectively, in the MPR and DPR configurations (Fig. 4).

Compared to the MBD and DBD configurations, benthic phosphorus regeneration does not turn our model domain into a smaller fixed-N source, in spite of higher water-column denitrification because enhanced nitrogen fixation compensates for the extra nitrogen loss (A bars in Fig. 4).

While changes in nitrogen deposition and benthic denitrification are to a large extent compensated for by adjustments in nitrogen fixation, phosphate is the ultimate limiting nutrient in our model domain (Su et al., 2015). Hence, the extra phosphate input into the model domain by benthic phosphorus regeneration has a more significant influence on the steady- 


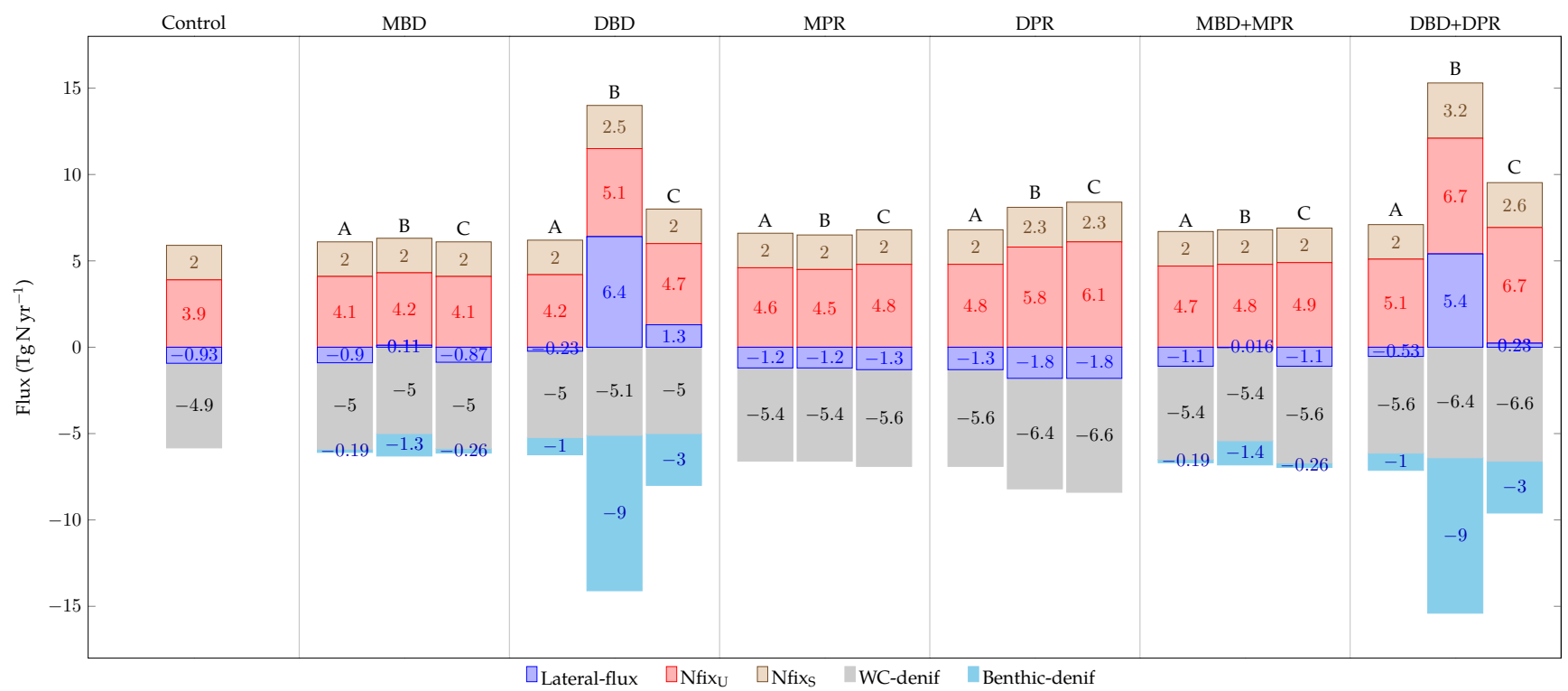

Figure 4. Nitrogen fluxes after including benthic denitrification and/or phosphorus regeneration. Lateral-flux is the nitrogen efflux or influx through the southern boundary; $\mathrm{Nfix}_{\mathrm{U}}$ and $\mathrm{Nfix}_{\mathrm{S}}$ represent the nitrogen fixation rate by $\mathrm{NF}$ in the $\mathrm{U}$ and $\mathrm{S}$ boxes, respectively; WC-denif is water-column denitrification; Benthic-denif represents the fixed-N loss via benthic denitrification in the model domain. Bar labels: A, main experiments; B, sensitivity experiments with high-BD; C, sensitivity experiments with Martin curve exponent $b=0.4$.

state model results than the perturbations of the nitrogen inputs or losses (Fig. 3). Phy concentration in the DPR configuration decreases in the $\mathrm{U}$ box but remains unchanged in the $\mathrm{S}$ box (Fig. S2). Phy concentrations in the $\mathrm{U}$ and $\mathrm{S}$ boxes remain almost unaltered in the MPR configuration. Compared with the control configuration, NF concentrations in the $\mathrm{U}$ and $\mathrm{S}$ boxes increase by 11 and $1.6 \%$, respectively, in the MPR configuration and by 14 and $1.6 \%$, respectively, in the DPR configuration (Fig. 3). The nitrate concentration in the UM box decreases by about $4.2 \%$ in the MPR configuration and $5.2 \%$ in the DPR configuration (Fig. S2). The temporal development of biogeochemical tracer concentrations appears robust to benthic phosphorus regeneration (Fig. S4).

\subsection{Synthesis configurations}

In the synthesis configurations (Table 1), phytoplankton, nutrient and oxygen concentrations are quite robust with respect to the various fluxes associated with nitrogen input or removal and phosphate release from the sediment into the water column (Fig. S2). However, the interactions among nitrogen fixation, water-column denitrification, and benthic denitrification and phosphorus regeneration result in different sensitivities of nitrogen fixation and of the lateral fluxes to atmospheric $\mathrm{N}$ deposition in the presence of benthic denitrification and phosphorus regeneration (Fig. 3). In contrast to the NDEP configuration, nitrogen fixation rates in the Syn3 and Syn 4 configurations increase by about 1.7 and $8.5 \%$, in spite of the additional nitrogen input into the model domain by atmospheric nitrogen deposition. Most of this increase oc- curs in the $\mathrm{U}$ box, whereas almost no change happens in the $\mathrm{S}$ box.

The lateral fixed-N flux out of the model domain $\left(\mathrm{NO}_{3}^{-}\right.$ source) increases by about $0.97 \mathrm{Tg} \mathrm{Nyr}^{-1}$ in the $\mathrm{Syn} 3$ configuration, which accounts for about $65 \%$ of the total atmospheric nitrogen deposition; i.e. more than half of the extra nitrogen supplied by nitrogen deposition is not utilised locally. However, in the Syn 4 configuration, the increase in lateral $\mathrm{NO}_{3}^{-}$efflux only accounts for about $25 \%$ of the total nitrogen deposition, with $75 \%$ of the deposited nitrogen utilised within the model domain. Less fixed $\mathrm{N}$ is lost laterally from the model domain in the configurations including data-based estimates than in those including model-based estimates, due to more $\mathrm{NO}_{3}^{-}$loss within the model domain (Fig. 4). Thus, the sensitivity of lateral fluxes and the fixed-N budget to nitrogen deposition is strongly controlled by benthic denitrification and phosphorus regeneration.

\subsection{Model sensitivity}

The nitrogen deposition rate estimated by Dentener et al. (2006) is about 48 and $14 \%$ higher, respectively, in the $\mathrm{U}$ and $S$ boxes than the estimate of Lamarque et al. (2011). However, this increase induces only a $3.1 \%$ decrease in nitrogen fixation in the $\mathrm{U}$ box and a $5.9 \%$ increase in lateral nitrogen flux, while water-column denitrification and nitrogen fixation in the $\mathrm{S}$ box remain unchanged (A and $\mathrm{B}$ bars in panel NDEP of Fig. 5). Whereas the uncertainty associated with the nitrogen deposition estimate of Dentener et al. (2006) amounts to about $\pm 40 \%$, the nitrogen fixation rate in the $\mathrm{U}$ box and 
lateral flux only vary by about \pm 9.7 and $\pm 20 \%$, respectively (panels NDEP-low and NDEP-up in Fig. 5). Effects of accounting for atmospheric deposition of bioavailable DON are investigated in three sensitivity experiments with different scenarios for DON bioavailability (panels NDEPDON(10\%), NDEP-DON(30\%) and NDEP-DON(50\%) in Fig. 5). Including bioavailable atmospheric DON in addition to DIN deposition causes only minor changes, i.e. slightly lower nitrogen fixation and slightly higher lateral nitrogen efflux. The RCP 8.5 scenario projects about a $7.2 \%$ increase in nitrogen deposition for the year 2100 compared to our main experiment (2000-2009 average according to the RCP 4.5 scenario), causing only negligible changes to the nitrogen budget in our model domain (A bars in panels NDEP and NDEP-2100 of Fig. 5). These sensitivity experiments show that variations in nitrogen deposition are largely offset by changes in nitrogen fixation and lateral nitrogen flux out of the model domain, tending to keep a balanced nitrogen inventory.

The effect of aphotic nitrogen fixation is investigated in the AphoticNfix 1 and AphoticNfix 2 configurations, where photic nitrogen fixation decreases by 39 and $15 \%$, respectively (Fig. S5). Water-column denitrification remains unchanged because more nitrogen input by aphotic nitrogen fixation does not increase export production to the OMZ. The lateral fixed-N effluxes in the AphoticNfix1 and AphoticNfix 2 configurations are about 33 and 4 times those in the control configuration, accounting for about 91 and $78 \%$, respectively, of extra nitrogen input by aphotic nitrogen fixation (Fig. S5). Aphotic $\mathrm{N}_{2}$ fixation has little effect on most tracers except $\mathrm{NO}_{3}^{-}$, which increases by 110 and $87 \%$, respectively, in the UM box and the whole model domain for AphoticNfix1, which is a strong overestimate compared to WOA 2009 data (Fig. S6). The lower estimate of aphotic $\mathrm{N}_{2}$ fixation (AphoticNfix2) brings the $\mathrm{NO}_{3}^{-}$concentrations closer to the WOA 2009 data (Fig. S6), and the associated changes in nitrogen fluxes are similar to our other sensitivity configurations (Figs. 5 and S5). As for the sensitivity with respect to atmospheric nitrogen deposition, these changes are largely compensatory, leading to only small changes in the nitrogen budget of our model domain.

Figure 6 shows the results of the sensitivity experiments with high-BD and high-PR. Compared with Fig. 3, the influence on the biogeochemical tracer concentrations in steady state is stronger, due to the larger $\mathrm{NO}_{3}^{-}$loss via benthic denitrification and $\mathrm{PO}_{4}^{3-}$ release via phosphorus regeneration (Table 2). High-BD or high-BD together with high-PR can even turn our model domain into an $\mathrm{NO}_{3}^{-}$sink (B bars in panels DBD and DBD+DPR of Fig. 4).

Applying the Martin curve exponent $b=0.4$ also amplifies the influence of benthic denitrification and phosphorus regeneration on phytoplankton and biogeochemical tracers, although the effect is weaker than in the high-BD and high$\mathrm{PR}$ configurations. For example, $\mathrm{NF}_{\mathrm{U}}$ increases by as much as $33 \%$ in the DBD+DPR configuration, and $\mathrm{NF}_{\mathrm{S}}$ increase about $15 \%$ (Fig. 7). Compared with A bars in Fig. 4, this enhanced influence results from the higher $\mathrm{NO}_{3}^{-}$loss through benthic denitrification and phosphate input via phosphorus regeneration (C bars in Fig. 4).

Spatial variations in the Martin curve exponent $b$ as suggested by Guidi et al. (2015) result in nitrogen fluxes and concentrations in steady state which are in good agreement with those in our main configurations (A and $\mathrm{C}$ bars in Figs. S7 and S8) because the $b$ values from Guidi et al. (2015) are all very close to $b=0.82$, as used in our main configurations.

Due to the higher RRPOC reaching the sea floor under suboxic conditions, benthic denitrification increases by about 42 and $198 \%$ (A and C bars of panels MBD and DBD in Fig. 4) and phosphorus regeneration increases by about 36 and $200 \%$, respectively, in model- and data-based estimations in the sensitivity experiments with Martin curve value $b=0.4$. Our model domain switches to a $\mathrm{NO}_{3}^{-}$sink in the DBD and DBD + DPR configurations with $b=0.4$ (C bars in Fig. 4). Comparing the $\mathrm{A}$ and $\mathrm{C}$ bars of panel DBD in Fig. 4, we find that higher benthic denitrification can stimulate nitrogen fixation, but water-column denitrification remains constant. However, comparing the $\mathrm{A}$ and $\mathrm{C}$ bars of panel DBD+DPR in Fig. 4, we find that higher benthic denitrification can increase nitrogen fixation and water-column denitrification, indicating an important role of $\mathrm{PO}_{4}^{3-}$ in balancing the nitrogen inventory. This shows a positive feedback between water-column denitrification in the OMZ and benthic denitrification below, caused by slower remineralisation under anoxic conditions, which results in more RRPOC reaching the sea floor. All above comparisons indicate that phosphate limitation could be responsible for breaking this positive feedback under the assumption of our model that $\mathrm{PO}_{4}^{3-}$ is the only limiting factor for the growth of nitrogen fixers.

\section{Discussion and conclusions}

The impact of nitrogen deposition on the ETSP has rarely been investigated so far, since this region is believed to receive less bioavailable nitrogen from atmospheric deposition than the coasts of western Europe, south and east Asia (Dentener et al., 2006; Duce et al., 2008). The influence of anthropogenic nitrogen deposition on the biogeochemical cycles of the open ocean is increasing and the increase in atmospheric nitrogen deposition will probably induce an approximately $10 \%$ rise in carbon sequestration on land and in the ocean by 2030 (Duce et al., 2008; Reay et al., 2008). The ETSP, a typical $\mathrm{N}$-deficit region due to denitrification in the OMZ, is likely to be sensitive to anthropogenic nitrogen deposition. We find that, in our model, nitrogen deposition can inhibit $\mathrm{N}_{2}$ fixation by relieving nitrogen limitation for Phy, which counteracts the effect of atmospheric nitrogen input. This is in line 


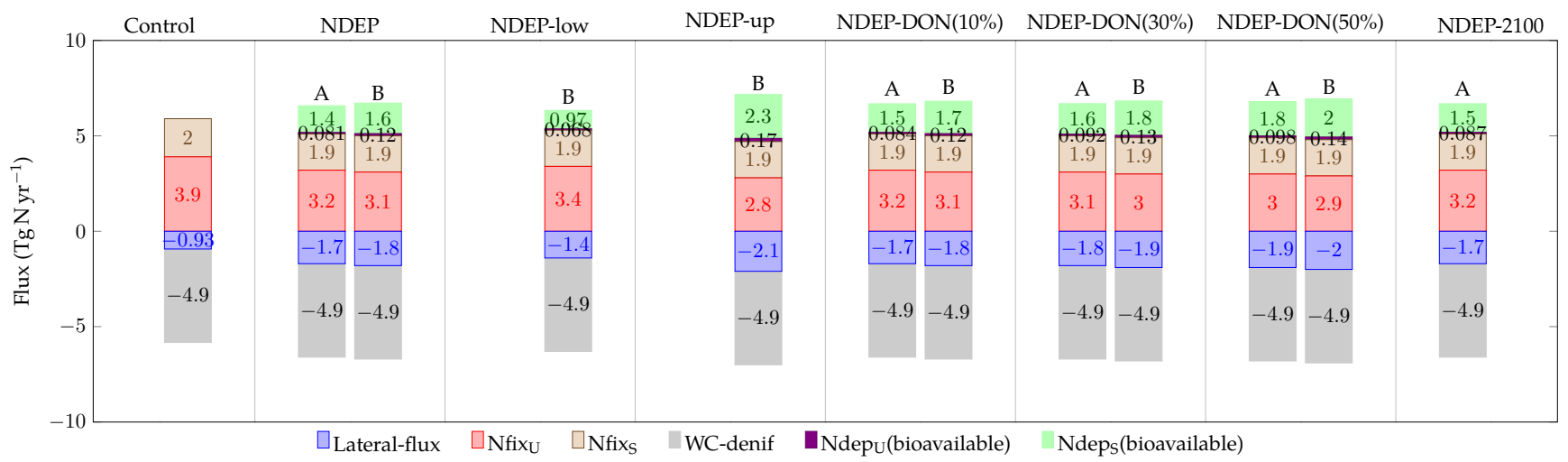

Figure 5. Sensitivity of nitrogen fluxes to atmospheric inorganic and organic nitrogen deposition and associated uncertainties. Lateralflux is the nitrogen efflux or influx through the southern boundary; Nfix $\mathrm{U}_{\mathrm{U}}$ and $\mathrm{Nfix}_{\mathrm{S}}$ represent the bioavailable nitrogen fixation rate by $\mathrm{NF}$ in the $\mathrm{U}$ and $\mathrm{S}$ boxes, respectively; WC-denif is water-column denitrification; NdepU and Ndeps are the nitrogen input into surface ocean (U and S boxes) via nitrogen deposition. Bar labels: A, nitrogen deposition data from Lamarque et al. (2011); B, nitrogen deposition data from Dentener et al. (2006). In NDEP-low and NDEP-up, the lower and upper limit of nitrogen deposition fluxes are included; in NDEP-DON(10\%), NDEP-DON(30\%) and NDEP-DON(50\%), the bioavailability of deposited DON is assumed to be 10,30 and $50 \%$, respectively; in NDEP-2100, nitrogen deposition is estimated according to the RCP8.5 scenario projections for 2100 (Lamarque et al., 2011 ).

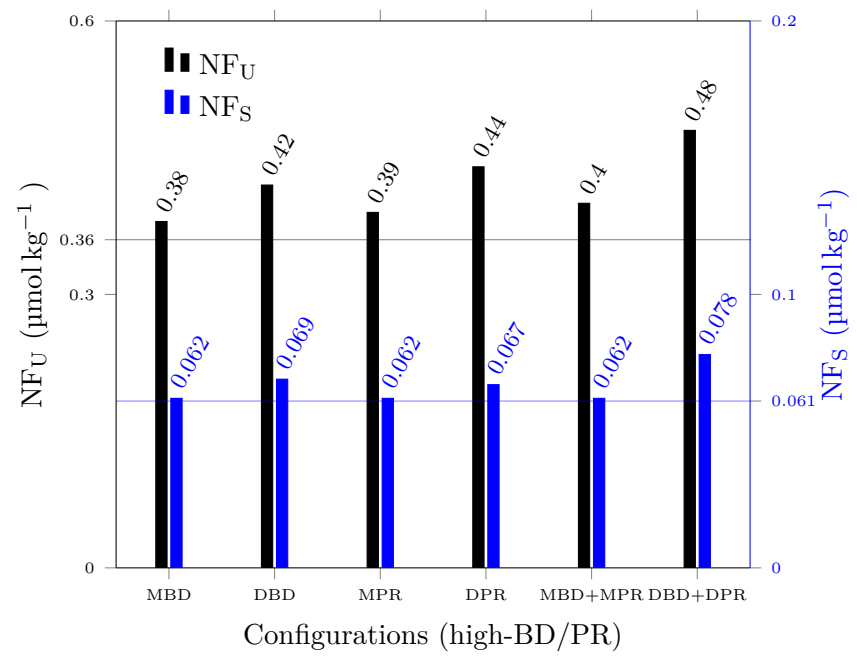

Figure 6. Sensitivity of simulated steady-state concentrations of nitrogen fixers $\left(\mathrm{NF}_{\mathrm{U}}\right.$ and $\left.\mathrm{NF}_{\mathrm{S}}\right)$ in the $\mathrm{U}$ and $\mathrm{S}$ boxes, respectively, after incorporating high-BD and high-PR. Horizontal grey and light blue lines represent the $\mathrm{NF}_{\mathrm{U}}$ and $\mathrm{NF}_{\mathrm{S}}$ concentrations in the control configuration.

with the finding that $\mathrm{N}_{2}$ fixation decreases with increasing nitrogen deposition in global-scale models that use essentially the same assumptions about the environmental controls on marine nitrogen fixation (Krishnamurthy et al., 2007, 2009, 2010; Zamora et al., 2010). Another portion of the deposited nitrogen is exported out of the model domain since not all the deposited nitrogen can be taken up by Phy locally, owing to phosphate limitation (Fig. 2).

The coastal upwelling region (the $\mathrm{U}$ box) in our model is more sensitive to nitrogen deposition due to the $\mathrm{N}$-deficit wa-

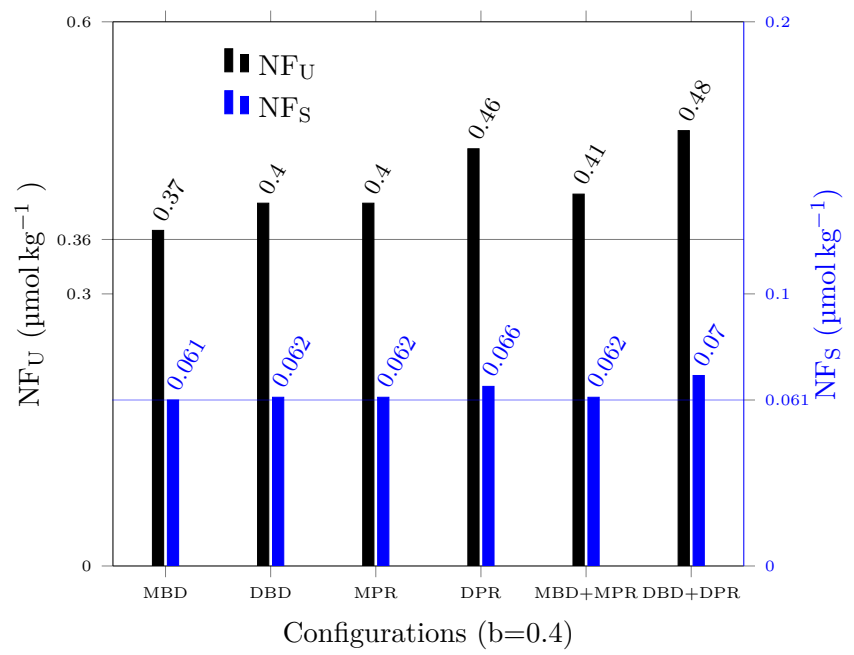

Figure 7. Sensitivity of simulated steady-state concentrations of nitrogen fixers $\left(\mathrm{NFU}_{\mathrm{U}}\right.$ and $\left.\mathrm{NF}_{\mathrm{S}}\right)$ in the $\mathrm{U}$ and $\mathrm{S}$ boxes, respectively, after applying $b=0.4$ for Eq. (2). Horizontal grey and light blue lines represent the $\mathrm{NF}_{U}$ and $\mathrm{NF}_{\mathrm{S}}$ concentrations in the control configuration.

ter supplied by upwelling (Fig. 5). In spite of the uncertainties in the magnitude of atmospheric bioavailable nitrogen deposition and the bioavailability of deposited DON, atmospheric deposition appears unable to exert a strong influence on the fixed-N budget of our model domain, as nitrogen deposition is mostly counteracted by decreased nitrogen fixation and enhanced nitrogen export out of the model domain.

Replacing obligate $\mathrm{N}_{2}$ fixation in our model by facultative $\mathrm{N}_{2}$ fixation slightly enhances the strength of the negative 


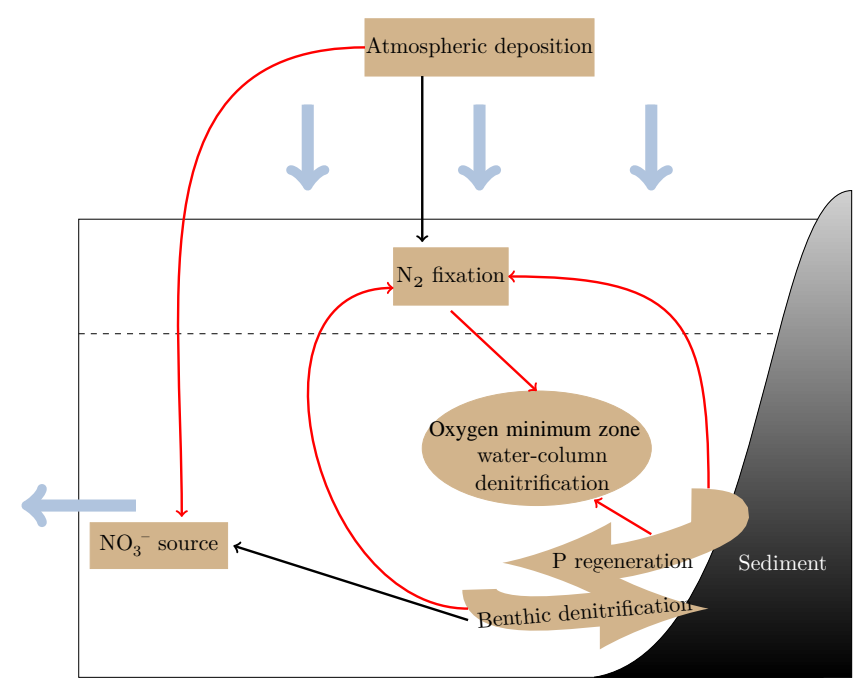

Figure 8. Schematic of the model sensitivity to different processes related to the nitrogen budget of the ETSP. The red solid lines represent stimulatory effects, and the black solid lines represent depressive effects.

feedback between nitrogen fixation and nitrogen deposition (see Sect. S1 in the Supplement for details).

The NPP estimated in our study is on average 1.4 and $0.87 \mathrm{~g} \mathrm{C} \mathrm{m}^{-2} \mathrm{~d}^{-1}$, respectively, in the surface ocean above the UM and D boxes, according to the carbon-based approach of Behrenfeld et al. (2005). Pennington et al. (2006) estimated NPP from ship-collected data as, respectively, 1.2 and $0.67 \mathrm{~g} \mathrm{C} \mathrm{m}^{-2} \mathrm{~d}^{-1}$ for the surface ocean above the UM and D boxes, whereby the NPP for the surface ocean above the D box could be somewhat overestimated because the western boundary for their data is $140^{\circ} \mathrm{W}$. Our estimates are about 17 and $30 \%$ higher than those of Pennington et al. (2006) for the surface ocean above the UM and D boxes because the carbon-based approach of Behrenfeld et al. (2005) yields considerably higher values than other approaches for tropical regions. Export production is linearly related to RRPOC (Eq. 2), as is RRPOC to BD (Eq. 1). PR and RRPOC are related through a power law with exponents of 1.11 and 1.05 for the UM and D boxes, respectively (Eqs. 5-8). Fixed$\mathrm{N}$ loss via $\mathrm{BD}$ and $\mathrm{PO}_{4}^{3-}$ release by PR estimated with shipcollected data should thus be within the range corresponding to the NPP estimates from Behrenfeld et al. (2005) and Pennington et al. (2006). However, in our data-based estimation of $\mathrm{BD}$ and $\mathrm{PR}$, the fixed-N loss by $\mathrm{BD}$ and $\mathrm{PO}_{4}^{3-}$ release by PR is, respectively, 421 and $140 \%$ higher than our model-based estimates. Therefore, the NPP estimated from ship-collected data lead to benthic remineralisation fluxes between our data-based and model-based estimations.

Aphotic nitrogen fixation, i.e. below the euphotic zone, has been considered an important contribution to the nitrogen budget of the ETSP (Bonnet et al., 2013). Our model configurations including aphotic $\mathrm{N}_{2}$ fixation are in line with this view, as the large amount of additional nitrogen input in the AphoticNfix 1 configuration induces overestimation of $\mathrm{NO}_{3}^{-}$ concentrations in the model domain, whereas $\mathrm{NO}_{3}^{-}$concentration is closer to the WOA 2009 data in the AphoticNfix 2 configuration, which has a much lower aphotic nitrogen fixation rate. Due to the very sparse data for aphotic $\mathrm{N}_{2}$ fixation, we had to extrapolate the data for the coastal region to the vast open ocean of the ETSP, which could have led to an overestimation of aphotic nitrogen fixation. Thus, we expect that aphotic $\mathrm{N}_{2}$ fixation is likely closer to the lower (2011) estimate of Bonnet et al. (2013), as the resulting $\mathrm{NO}_{3}^{-}$concentrations are closer to the WOA 2009 data.

Table 3 shows our modelled fluxes in comparison with other model-based and observational estimates. $\mathrm{N}_{2}$ fixation in the upwelling region of our model is higher than those reported by Somes et al. (2010), DeVries et al. (2013), and Dekaezemacker et al. (2013) but within the range suggested by Loescher et al. (2014). However, the $\mathrm{N}_{2}$ fixation rate in the open ocean of our model is lower than those by Somes et al. (2010) and DeVries et al. (2013) but within the range suggested by Halm et al. (2012). Water-column denitrification is comparable to Somes et al. (2010) and DeVries et al. (2013) but lower than that from Kalvelage et al. (2013). Our predicted fixed-N loss by benthic denitrification is comparable to other estimates. Phosphorus regeneration in our analysis spans a wide range but is comparable to the evaluation of Bohlen et al. (2012) for the full depth of the model domain. Major nitrogen and phosphorus fluxes in our study also span wide ranges because fluxes both from the upper $2000 \mathrm{~m}$ and full depth of the ocean are assessed with both data and model-based evaluations, in each case accounting for organic-matter remineralisation under different oxygen conditions (Table 3). Currently, both global and regional estimates of nitrogen fixation and benthic remineralisation rates are rather uncertain, owing to temporal and spatial variations and problems associated with measuring methods (e.g. Mohr et al., 2010). Thus, we had to apply rather wide ranges in order to investigate the potential influence of these processes on the nitrogen budget of our model domain.

Under the assumption that $\mathrm{N}_{2}$ fixation compensates for any fixed-N deficit (Deutsch et al., 2007), nitrogen fixation can be stimulated by benthic denitrification. Somes et al. (2013) found that benthic denitrification stimulates $\mathrm{N}_{2}$ fixation in their 3-D biogeochemical model, which was tuned under the condition that the global fixed-N budget was balanced. Even though we make no a priori assumption about the association between $\mathrm{N}_{2}$ fixation and fixed-N loss processes, we also find that a fixed-N deficit can stimulate $\mathrm{N}_{2}$ fixation, thus compensating for the fixed-N loss.

We find that incorporating benthic phosphorus regeneration strongly increases primary production, which is mainly attributed to nitrogen fixation (panels MPR and DPR in Fig. 4). Phosphorus regeneration is enhanced under $\mathrm{O}_{2}$ deficit conditions, and the enhanced phosphate release stimu- 
Table 3. Model flux comparison with model-based and observational estimates.

\begin{tabular}{lrrrr|r}
\hline Reference & \multicolumn{2}{c|}{$\mathrm{N}_{2}$ fixation } & WC-denif & BD & PR \\
\hline & \multicolumn{3}{c|}{ (Tg N yr $\left.^{-1}\right)$} & & $\left(\mathrm{Tg} \mathrm{P} \mathrm{yr}^{-1}\right)$ \\
& $\mathrm{U}$ box & $\mathrm{S}$ box & & \\
\hline This study $^{\mathrm{a}}$ & $2.8-6.7$ & $1.9-3.2$ & $4.9-6.6$ & $0.19-9.0^{\mathrm{f}, \mathrm{g}}$ & $0.062-0.62^{\mathrm{f}, \mathrm{g}}$ \\
Somes et al. (2010) $^{\mathrm{a}, \mathrm{b}}$ & 0.086 & 4.4 & 5.7 & $0.86^{\mathrm{f}}$ & \\
Halm et al. (2012) $^{\mathrm{c}}$ & & $1.4-21^{\mathrm{e}}$ & & & \\
Bohlen et al. (2012) $^{\mathrm{a}}$ & & & & $2.0^{\mathrm{f}}$ & $0.34^{\mathrm{f}}$ \\
Kalvelage et al. (2013) $^{\mathrm{c}}$ & & & 10 & $1.0^{\mathrm{h}}$ & \\
DeVries et al. (2013) $^{\mathrm{a}, \mathrm{b}}$ & $0.4 \pm 0.1$ & $13 \pm 4.0$ & $7.0 \pm 2.0$ & $6.0 \pm 2.0^{\mathrm{f}}$ & \\
Dekaezemacker et al. (2013) $^{\mathrm{c}}$ & $0.023-0.30^{\mathrm{d}}$ & & & & \\
Loescher et al. (2014) $^{\mathrm{c}}$ & $0.22-18.7^{\mathrm{d}}$ & & & & \\
\hline
\end{tabular}

a Model results. ${ }^{b}$ Personal communication. ${ }^{c}$ Observational estimates. ${ }^{\mathrm{d}}$ Value extrapolated to the area of the U box in our model.

${ }^{\mathrm{e}}$ Value extrapolated to the area of the $\mathrm{S}$ box in our model. ${ }^{\mathrm{f}}$ For the whole sediment area below our model domain. ${ }^{\mathrm{g}}$ Top $2000 \mathrm{~m}$ of our model domain. ${ }^{\mathrm{h}}$ Top $600 \mathrm{~m}$ of the OMZ region.

lates primary production, resulting in the expansion of OMZs and possibly causing a positive feedback loop leading to more benthic phosphorus regeneration (Van Cappellen and Ingall, 1994; Wallmann, 2010). However, our model domain only represents the upper $2000 \mathrm{~m}$ of the ocean and its sediments only account for a small fraction of the total sediment area in the ETSP. The model results incorporating benthic denitrification and phosphorus regeneration, and assuming that all of the D box is in contact with the sediment, are shown in Figs. 4 and 6. Our parameterisation allows nitrogen fixation to be favoured in $\mathrm{N}$-deficit waters, since the increase in water-column denitrification can be compensated for by increased nitrogen fixation when phosphorus regeneration is sufficient (panels MPR and DPR in Fig. 4).

The simplicity and computational efficiency of our box model facilitates exploring model sensitivity to various processes related to the nitrogen budget of the ETSP. Even though details of spatial and temporal variations are missing compared with results from 3-D global circulation models (Krishnamurthy et al., 2007, 2010; Zamora et al., 2010), we can efficiently diagnose the regional impacts in steady state. We identify stimulatory effects between nitrogen fixation and water-column denitrification, phosphorus regeneration and nitrogen fixation, phosphorus regeneration and water-column denitrification, and atmospheric deposition and lateral $\mathrm{NO}_{3}^{-}$ transport (Fig. 4). Depressive effects occur between atmospheric deposition and nitrogen fixation and between benthic denitrification and lateral $\mathrm{NO}_{3}^{-}$transport (Fig. 4). The model sensitivity to processes related to the nitrogen budget of the OMZ in the ETSP is illustrated in Fig. 8. Nitrogen fixation can be enhanced by benthic denitrification, compensating for part of the $\mathrm{NO}_{3}^{-}$loss. The stimulatory effect between nitrogen fixation and water-column denitrification helps balance the fixed-N budget. The extra fixed-N input by nitrogen deposition is partly counteracted by decreased nitrogen fixation and partly removed by lateral flux. All of these local responses combined constitute a nitrogen-balancing mechanism in the ETSP. Even though water-column denitrification has been considered to be the major fixed-N loss process for simplicity, the stimulatory effects between nitrogen fixation and fixed-N loss and between phosphorus regeneration and fixed-N loss still apply even if anammox replaced watercolumn denitrification as the fixed-N loss pathway. Thus, the nitrogen-balancing mechanism in the ETSP should not depend on whether the fixed-N is lost through denitrification or anammox.

In the high-BD sensitivity experiment, our model domain turns into an $\mathrm{NO}_{3}^{-}$sink (Fig. 4). The $\mathrm{NO}_{3}^{-}$inventory in the ETSP is determined by nitrogen fixation, water-column denitrification, benthic denitrification and lateral $\mathrm{NO}_{3}^{-}$flux. Since our model domain (except in the high-BD sensitivity configuration) encompasses only the water column and a small fraction of the corresponding sediment area, we cannot rule out that the ETSP including sedimentary denitrification is an $\mathrm{NO}_{3}^{-}$sink, which is consistent with many model- or dataderived results (Ganachaud and Wunsch, 2002; Kalvelage et al., 2013). Extra phosphate input into the model domain via phosphorus regeneration can increase water-column denitrification significantly due to the increase in EP from the surface ocean. However, phosphorus regeneration alone cannot turn our model domain into an $\mathrm{NO}_{3}^{-}$sink.

The remineralisation rate of organic matter is thought to be reduced under anoxic conditions (Martin et al., 1987; Van Mooy et al., 2002), resulting in a higher RRPOC reaching the sediments. According to the analysis of Bohlen et al. (2012), benthic denitrification is very sensitive to RRPOC; i.e. higher RRPOC results in higher benthic denitrification. Based on our findings that higher benthic denitrification can increase nitrogen fixation, higher nitrogen fixation could result in higher water-column denitrification and the expansion of the OMZ and hence a positive feedback between watercolumn and benthic denitrification. But this positive feed- 
back is only observed in configurations with phosphate input via phosphorus regeneration, which indicates that $\mathrm{PO}_{4}^{3-}$ limitation could play an important role in preventing this positive fixed-N loss feedback.

\section{Summary}

The influence of atmospheric nitrogen deposition and benthic remineralisation on the nitrogen budget of the ETSP is investigated with a conceptually simple and computationally efficient box model. Additional nitrogen input by atmospheric nitrogen deposition is offset by about $48 \%$ by reduced nitrogen fixation, with the remainder being transported horizontally out of the model domain, irrespective of uncertainties underlying the actual rate of nitrogen deposition and bioavailability of deposited DON. All our data- and modelbased estimations for benthic remineralisation are comparable to those of previous studies based on both models and observations. Modelled responses to these fluxes indicate stabilising feedbacks, which tend to balance the nitrogen inventory. Variations in these fluxes due to variations in NPP, aphotic nitrogen fixation and organic-matter remineralisation under different oxygen conditions do not change these feedbacks. In the high-BD configuration, our model domain turns into an $\mathrm{NO}_{3}^{-}$sink, which indicates that the whole ETSP, including the upwelling region, the open ocean and the sediments, might be an $\mathrm{NO}_{3}^{-}$sink. More research is needed to better constrain the fluxes of nitrogen and phosphorus, including the amount of bioavailable nitrogen deposition, nitrogen fixation and benthic denitrification, to allow a more reliable estimation of the nitrogen budget of the ETSP.

\section{Data availability}

Except for the sources of datasets described in the "Model description" section of this paper, the model codes and model outputs for nitrogen deposition from Dentener et al. (2006) and Lamarque et al. (2011) are available via http://thredds. geomar.de. For the data applied for flux comparison, please refer to the cited publications.

\section{The Supplement related to this article is available online at doi:10.5194/bg-13-4985-2016-supplement.}

Author contributions. All co-authors jointly conceived and designed this study. Bei Su performed all model simulations and data analysis. Bei Su prepared the manuscript with contributions from all co-authors.
Acknowledgements. The authors wish to acknowledge funding from CSC (Chinese Scholarship Council), from the Sonderforschungsbereich 754 "Climate-Biogeochemistry Interaction in the Tropical Ocean" (www.sfb754.de) supported by the Deutsche Forschungsgemeinschaft and from the Cluster of Excellence "The Future Ocean", Kiel, Germany. The authors also wish to thank Wolfgang Koeve, Paul Kähler and two anonymous reviewers for the great help in improving this manuscript and Frank Dentener, Lauren Zamora, Jean-François Lamarque, Andy Dale, Lisa Bohlen, Christopher Somes and Tim DeVries for generously providing their data and model results.

Edited by: V. Garçon

Reviewed by: two anonymous referees

\section{References}

Auguéres, A.-S. and Loreau, M.: Regulation of Redfield ratios in the deep ocean, Global Biogeochem. Cy., 29, 254-266, 2015.

Bakun, A. and Weeks, S. J.: The marine ecosystem off peru: what are the secrets of its fishery productivity and what might its future hold?, Prog. Oceanogr., 79, 290-299, 2008.

Behrenfeld, M. J., Boss, E., Siegel, D. A., and Shea, D. M.: Carbonbased ocean productivity and phytoplankton physiology from space, Global Biogeochem. Cy., 19, 1-14, 2005.

Berelson, W. M.: The flux of particulate organic carbon into the ocean interior: a comparison of four US JGOFS regional studies, Oceanography, 14, 59-67, 2001.

Bohlen, L., Dale, A. W., Sommer, S., Mosch, T., Hensen, C., Noffke, A., Scholz, F., and K. Wallmann: Benthic nitrogen cycling traversing the Peruvian oxygen minimum zone, Geochim. Cosmochim. Ac., 75, 6094-6111, 2011.

Bohlen, L., Dale, A. W., and K. Wallmann: Simple transfer functions for calculating benthic fixed nitrogen losses and $\mathrm{C}: \mathrm{N}: \mathrm{P}$ regeneration ratios in global biogeochemical models, Global Biogeochem. Cy., 26, 1-16, 2012.

Bonnet, S., Dekaezemacker, J., Turk-Kubo, K. A., Moutin, T. Hamersley, R. M., Grosso, O., Zehr, J. P., and Capone, D. G.: Aphotic $\mathrm{N}_{2}$ fixation in the eastern tropical south pacific ocean, PLoS One, 8, e81265, doi:10.1371/journal.pone.0081265, 2013.

Brandes, J. A. and Devol, A. H.: A global marine-fixed nitrogen isotopic budget: Implications for holocene nitrogen cycling, Global Biogeochem. Cy., 16, 1-14, 2002.

Canfield, D. E.: Models of oxic respiration, denitrification and sulfate reduction in zones of coastal upwelling, Geochim. Cosmochim. Ac., 70, 5753-5765, 2006.

Christensen, J. P., Murray, J. W., Devol, A., and Codispoti, L. A.: Denitrification in the continental shelf sediment has major impact on the oceanic nitrogen budget, Global Biogeochem. Cy., 1, 97116, 1987.

Clarke, L., Edmonds, J., Jacoby, H., Pitcher, H., Reilly, J., and Richels, R.: Scenarios of Greenhouse Gas Emissions and Atmospheric Concentrations: Synthesis and Assessment Product 2.1a Report by the US Climate Change Science Program and the Subcommittee on Global Change Research, Technical Report, Department of Energy, Office of Biological and Environmental Research, Washington, DC, USA, 2007. 
Codispoti, L. A.: An oceanic fixed nitrogen sink exceeding $400 \mathrm{Tg} \mathrm{N} \mathrm{a}^{-1}$ vs the concept of homeostasis in the fixed-nitrogen inventory, Biogeosciences, 4, 233-253, doi:10.5194/bg-4-2332007, 2007.

Codispoti, L. A., Brandes, J., Christensen, J., Devol, A., Naqvi, S. W., Paerl, H., and Yoshinari, T.: The oceanic fixed nitrogen and nitrous oxide budgets: moving targets as we enter the anthropocene?, Sci. Mar., 65, 85-105, 2001.

Cornell, S. E., Jickells, T. D., Cape, J. N., Rowland, A. P., and Duce, R. A.: Organic nitrogen deposition on land and coastal environments: a review of methods and data, Atmos. Environ., 37, 2173-2191, 2003.

Dentener, F., Drevet, J., Lamarque, J. F., Bey, I., Eickhout, B., Fiore, A. M., Hauglustaine, D., Horowitz, L. W., Krol, M., Kulshrestha, U. C., Lawrence, M., Galy-Lacaux, C., Rast, S., Shindell, D., Stevenson, D., Noije, T. V., Atherton, C., Bell, N., Bergman, D., Butler, T., Cofala, J., Collins, B., Doherty, R., Ellingsen, K., Galloway, J., Gauss, M., Montanaro, V., Müller, J. F., Pitari, G., Rodriguez, J., Sanderson, M., Solmon, F., Strahan, S., Schultz, M., Sudo, K., Szopa, S., and Wild, O.: Nitrogen and sulfur deposition on regional and global scales: a multimodel evaluation, Global Biogeochem. Cy., 20, 1-21, GB4003, doi:10.1029/2005GB002672, 2006.

Dekaezemacker, J., Bonnet, S., Grosso, O., Moutin, T., Bressac, M., and Capone, D.: Evidence of active dinitrogen fixation in surface waters of the eastern tropical south pacific during el niño and la niña events and evaluation of its potential nutrient controls, Global Biogeochem. Cy., 27, 768-779, 2013.

Deutsch, C., Gruber, N., Key, R. M., Sarmiento, J. L., and Ganachaud, A.: Denitrification and $\mathrm{N}_{2}$ fixation in the Pacific Ocean, Global Biogeochem. Cy., 15, 483-506, 2001.

Deutsch, C., Sarmiento, J. L., Sigman, D. M., Gruber, N., and Dunne, J. P.: Spatial coupling of nitrogen inputs and losses in the ocean, Nature, 445, 163-167, 2007.

Devol, A. H.: Direct measurement of nitrogen gas fluxes from continental shelf sediments, Nature, 349, 319-321, 1991.

DeVries, T., Deutsch, C., Primeau, F., Chang, B., and Devol, A.: Global rates of water-column denitrification derived from nitrogen gas measurements, Nature, 5, 547-550, 2012.

DeVries, T, Deutsch, C, Rafter,P. A., and Primeau, F.: Marine denitrification rates determined from a global 3-d inverse model, Biogeosciences, 10, 2481-2496, doi:10.5194/bg-10-2481-2013, 2013.

Duarte, C. M., Dachs, J., Llabrés, M., Alonso-Laita, P., Gasol, J. M., Tovar-Sánchez, A., Sañudo-Wilhemy, S. S., and Agustí, S.: Aerosol inputs enhance new production in the subtropical northeast Atlantic, J. Geophys. Res., 111, G04006, doi:10.1029/2005JG000140, 2006.

Duce, R. A.: The impact of atmospheric nitrogen, phosphorus, and iron species on marine biological productivity, in: The Role of Air-Sea Exchange in Geochemical Cycling, vol. 185 of NATO ASI Series, edited by: P. Buat-Ménard, Springer, New York, 497529, 1986

Duce, R. A., Liss, P. S., Merrill, J. T., Atlas, E. L., Buat-Menard, P., Hicks, B. B., Miller, J. M., Prospero, J. M., Arimoto, R., Church, T. M., Ellis, W., Galloway, J. N., Hansen, L., Jickells, T. D., Knap, A. H., Reinhardt, K. H., Schneider, B., Soudine, A., Tokos, J. J., Tsunogai, S., Wollast, R., and Zhou, M.:
The atmospheric input of trace species to the world ocean, Global Biogeochem. Cy., 5, 193-259, 1991.

Duce, R. A., LaRoche, J., Altieri, K., Arrigo, K. R., Baker, A. R., Capone, D. G., Cornell, S., Dentener, F., Galloway, J., Ganeshram, R. S., Geider, R. J., Jickells, T., Kuypers, M. M., Langlois, R., Liss, P. S., Liu, S. M., Middelburg, J. J., Moore, C. M., Nickovic, S., Oschlies, A., Pedersen, T., Prospero, J., Schlitzer, R., Seitzinger, S., Sorensen, L. L., Uematsu, M., Ulloa, O., Voss, M., Ward, B., and Zamora, L.: Impacts of atmospheric anthropogenic nitrogen on the open ocean, Science, 320, 893-897, 2008.

Dunne, J. P., Armstrong, R. A., Gnanadesikan, A., and Sarmiento, J. L.: Empirical and mechanistic models for the particle export ratio, Global Biogeochem. Cy., 19, GB4026, doi:10.1029/2004GB002390, 2005.

Eugster, O. and Gruber, N.: A probabilistic estimate of global marine N-fixation and denitrification, Global Biogeochem. Cy., 26, GB4013, doi:10.1029/2012GB004300, 2012.

Falkowski, P. G., Barber, R. T., and Smetacek, V.: Biogeochemical Controls and Feedbacks on Ocean Primary Production, Science, 281, 200-206, 1998.

Flögel, S., Wallmann, K., Poulsen, C. J., Zhou, J., Oschlies, A., Voigt, S., and Kuhnt, W.: Simulating the biogeochemical effects of volcanic $\mathrm{CO}_{2}$ degassing on the oxygen-state of the deep ocean during the Cenomanian/Turonian Anoxic Event (OAE2), Earth Planet. Sc. Lett., 305, 371-384, 2011.

Ganachaud, A. and Wunsch, C.: Oceanic nutrients and oxygen transports and bounds on export production during the world ocean circulation experiment, Global Biogeochem. Cy., 16, 1$14,2002$.

Garcia, H. E., Locarnini, R. A., Boyer, T. P., Antonov, J. I., Baranova, O. K., Zweng, M. M., and Johnson, D. R.: Volume 3: Dissolved oxygen, apparent oxygen utilization, and oxygen saturation, in: World Ocean Atlas 2009, edited by: Levitus, S., NOAA Atlas NESDIS 70, US Government Printing Office, Washington, DC, p. 344, 2010a.

Garcia, H. E., Locarnini, R. A., Boyer, T. P., Antonov, J. I., Zweng, M. M., Baranova, O. K., and Johnson, D. R.: Volume 4: Nutrients (phosphate, nitrate, silicate), in: World Ocean Atlas 2009, edited by: Levitus, S., NOAA Atlas NESDIS 71, US Government Printing Office, Washington, DC, p. 398., 2010 b.

Großkopf, T., Mohr, W., Baustian, T., Schunck, H., Gill, D., Kuypers, M. M. M., Lavik, G., Schmitz, R. A., Wallace, D. W. R., and LaRoche, J.: Doubling of marine dinitrogen-fixation rates based on direct measurements, Nature, 488, 361-364, 2012.

Gruber, N.: The dynamics of the marine nitrogen cycle and its influence on atmospheric $\mathrm{CO}_{2}$ variations, in: The Ocean Carbon $\mathrm{Cy}$ cle and Climate, vol. 40 of NATO Science Series, chapt. 4, edited by: Follows, M. and Oguz, T., Kluwer Academic, P.O. Box 17, 3300 AA Dordrecht, the Netherlands, 97-148, 2004.

Gruber, N. and Sarmiento, J. L.: Large-scale biogeochemicalphysical interactions in elemental cycles, in: Biogeochemical/Physical Interactions in Elemental Cycles, vol. 12 of The Sea, chapt. 9, edited by: Robinson, A. R., Macarthy, J. J., Rothschild, B. J., J. Wiley and Sons, Harward University Press, 337399, New York, 2002.

Guidi, L., Legendre, L., Reygondeau, G., Uitz, J., Stemmann, L., and Henson, S. A.: A new look at ocean carbon remineralization 
for estimating deepwater sequestration, Global Biogeochem. Cy., 29, 1044-1059, 2015.

Halm, H., Lam, P., Ferdelman, T. G., Lavik, G., Dittmar, T., LaRoche, J., D'Hondt, S., and Kuypers, M. M.: Heterotrophic organisms dominate nitrogen fixation in the South Pacific Gyre, ISME J., 6, 1238-1249, 2012.

Holl, C. M. and Montoya, J. P.: Interactions between nitrate uptake and nitrogen fixation in continuous cultures of the marine diazotroph Trichodesmium (Cyanobacteria), J. Phycol., 41, 11781183, 2005.

Kalvelage, T., Lavik, G., Lam, P., Contreras, S., Arteaga, L., Löscher, C. R., Oschlies, A., Paulmier, A., Stramma, L., and Kuypers, M. M. M.: Nitrogen cycling driven by organic matter export in the South Pacific oxygen minimum zone, Nat. Geosci., 6, 228-234, 2013.

Kanakidou, M., Duce, R. A., Prospero, J. M., Baker, A. R., BenitezNelson, C., Dentener, F. J., Hunter, K. A., Liss,P. S., Mahowald, N., Okin, G. S., Sarin, M., Tsigaridis, K., Uematsu, M., Zamora, L. M., and Zhu, T.: Atmospheric fluxes of organic n and $\mathrm{p}$ to the global ocean, Global Biogeochem. Cy., 26, GB3026, doi:10.1029/2011GB004277, 2012.

Kasai, A., Kimura, S., Nakata, H., and Okazaki, Y.: Entrainment of coastal water into a frontal eddy of the kuroshio and its biological significance, J. Mar. Syst., 37, 185-198, 2002.

Key, R. M., Kozyr, A., Sabine, C. L., Lee, K., Wanninkhof, R. J., Bullister, L., Feely, R. A., Millero, F. J., Mordy, C., and Peng, T.H.: A global ocean carbon climatology: Results from Global Data Analysis Project (GLODAP), Global Biogeochem. Cy., 18, GB4031, doi:10.1029/2004GB002247, 2004.

Kim, I.-N., Lee, K., Gruber, N., Karl, D. M., Bullister, J. L., Yang, S., and Kim.,T.-W.: Increasing anthropogenic nitrogen in the North Pacific Ocean, Science, 346, 1102-1106, 2014.

Koeve, W. and Kähler, P.: Heterotrophic denitrification vs. autotrophic anammox - quantifying collateral effects on the oceanic carbon cycle, Biogeosciences, 7, 2327-2337, doi:10.5194/bg-7-2327-2010, 2010.

Krishnamurthy, A., Moore, J. K., Zender, C. S., and Luo, C.: Effects of atmospheric inorganic nitrogen deposition on ocean biogeochemistry, J. Geophys. Res., 112, G02019, doi:10.1029/2006JG000334, 2007.

Krishnamurthy, A., Moore, J. K., Mahowald, N., Luo, C., Doney, S. C., Lindsay, K., and Zender, C. S.: Impacts of increasing anthropogenic soluble iron and nitrogen deposition on ocean biogeochemistry, Global Biogeochem. Cy., 23, GB3016, doi:10.1029/2008GB003440, 2009.

Krishnamurthy, A., Moore, J. K., Mahowald, N., Luo, C., and Zender, C. S.: Impacts of atmospheric nutrient inputs on marine biogeochemistry, J. Geophys. Res., 115, G01006, doi:10.1029/2009JG001115, 2010.

Lam, P., Lavik, G., Jensen, M. M., van de Vossenberg, J., Schmid, M., Woebken, D., Gutiérrez, D., Amann, R., Jetten, M. S. M., and Kuypers, M. M. M.: Revising the nitrogen cycle in the Peruvian oxygen minimum zone, P. Natl. Acad. Sci. USA, 106, 4752-4757, 2009.

Lamarque, J.-F., Kyle, G. P., Meinshausen, M., Riahi, K., Smith, S. J., van Vuuren, D. P., Conley, A. J., and Vitt, F.: Global and regional evolution of short-lived radiatively-active gases and aerosols in the Representative Concentration Pathways, Climatic Change, 109, 191-121, 2011.
Lamarque, J. F., Dentener, F, McConnell, J, Ro, C. U., Shaw, M, Vet, R, Bergmann, D, Cameron-Smith, P, Dalsoren, S, Doherty, R, Faluvegi, G, Ghan, S. F, Josse, B, Lee, Y. H., MacKenzie, I. A., Plummer, D., Shindell, D. T., Skeie, R. B., Stevenson, D. S., Strode, S., Zeng, G, Curran, M., Dahl-Jensen, D, Das, S, Fritzsche, D, and Nolan, M.: Multi-model mean nitrogen and sulfur deposition from the Atmospheric Chemistry and Climate Model Intercomparison Project (ACCMIP): evaluation of historical and projected future changes, Atmos. Chem. Phys., 13, 7997-8018, doi:10.5194/acp-13-7997-2013, 2013.

Landolfi, A., Dietze, H., Koeve, W., and Oschlies, A.: Overlooked runaway feedback in the marine nitrogen cycle: the vicious cycle, Biogeosciences, 10, 1351-1363, doi:10.5194/bg-10-1351-2013, 2013.

La Roche, J. and Breitbarth, E.: Importance of the diazotrophs as a source of new nitrogen in the ocean, J. Sea Res., 53, 67-91, 2005.

Locarnini, R. A., Mishonov, A. V., Antonov, J. I., Boyer, T. P., Garcia, H. E., Baranova, O. K., Zweng, M. M., and Johnson, D. R.: Volume 1: Temperature, in: World Ocean Atlas 2009, NOAA Atlas NESDIS 68, edited by: Levitus, S., US Government Printing Office, Washington, DC, p. 184, 2010.

Loescher,C. R., Grokopf, T., Desai,F. D., Gill, D., Schunck, H., Croot,P. L., Schlosser, C., Neulinger,S. C., Pinnow, N., Lavik, G., Kuypers,M. M., LaRoche, J., and Schmitz,R. A.: Facets of diazotrophy in the oxygen minimum zone waters off peru, ISME J., 8, 2180-2192, 2014.

Mahowald, N., Jickells, T. D., Baker, A. R., Artaxo, P., BenitezNelson, C. R., Bergametti, G., Bond, T. C., Chen, Y., Cohen, D. D., Herut, B., Kubilay, N., Losno, R., Luo, C., Maenhaut, W., McGee, K. A., Okin, G. S., Siefert, R. L., and Tsukuda, S.: Global distribution of atmospheric phosphorus sources, concentrations and deposition rates, and anthropogenic impacts, Global Biogeochem. Cy., 22, GB4026, doi:10.1029/2008GB003240, 2008.

Martin, J. H., Knauer, G. A., Karl, D. M., and Broenkow, W. W.: VERTEX: carbon cycling in the northeast Pacific, Deep-Sea Res., 34, 267-285, 1987.

Mills, M. M., Ridame, C., Davey, M., La Roche, J., and Geider, R. J.: Iron and phosphorus co-limit nitrogen fixation in the eastern tropical North Atlantic, Nature, 429, 292-232, 2004.

Mohr, W., Grosskopf, T., Wallace, D. W. R., and La Roche, J.: Methodological underestimation of oceanic nitrogen fixation rates, PLoS ONE, 5, e12583, doi:10.1371/journal.pone.0012583, 2010.

Moore, C. M., Mills, M. M., Achterberg, E. P., Geider, R. J., La Roche, J., Lucas, M. I., McDonagh, E. L., Pan, X., Poulton, A. J., Rijkenberg, M. J. A., Suggett, D. J., Ussher, S. J., and Woodward, E. M. S.: Large-scale distribution of atlantic nitrogen fixation controlled by iron availability, Nat. Geosci., 2, 867-871, 2009.

Moore, C. M., Mills, M. M., Arrigo, K. R., Berman-Frank, I., Bopp, L., Boyd, P. W., Galbraith, E. D., Geider, R. J., Guieu, C., Jaccard, S. L., Jickells, T. D., LaRoche, J., Lenton, T. M., Mahowald, N. M., Marañón, E., Marinov, I., Moore, J. K., Nakatsuka, T., Oschlies, A., Saito, M. A., Thingstad, T. F., Tsuda, A., and Ulloa, O.: Processes and patterns of oceanic nutrient limitation, Nat. Geosci., 6, 701-710, 2013 
Moore, J. K. and Braucher, O.: Sedimentary and mineral dust sources of dissolved iron to the world ocean, Biogeosciences, 5 , 631-656, doi:10.5194/bg-5-631-2008, 2008.

Moss, R. H., Edmonds, J. A., Hibbard, K. A., Manning, M. R., Rose, S. K., van Vuuren, D. P., Carter, T. R., Emori, S., Kainuma, M., Kram, T., Meehl, G. A., Mitchell, J. F. B., Nakicenovic, N., Riahi, K., Smith, S. J., Stouffer, R. J., Thomson, A. M., Weyant, J. P., and Wilbanks, T. J.: The next generation of scenarios for climate change research and assessment, Nature, 463, 747-756, 2010.

Mouriño-Carballido, B., Pahlow, M., and Oschlies, A.: High sensitivity of ultra-oligotrophic marine ecosystems to atmospheric nitrogen deposition, Geophys. Res. Lett., 39, L05601, doi:10.1029/2011GL050606, 2012.

Noffke, A., Hensen, C., Sommer,S., Scholz, F., Bohlen, L., Mosch, T, Graco,M., and Wallmann, K.: Benthic iron and phosphorus fluxes across the Peruvian oxygen minimum zone, Limnol. Oceanogr., 57, 851-867, 2012.

Okin, G. S., Baker, A. R., Tegen, I., Mahowald, N. M., Dentener, F. J., Duce, R. A., Galloway, J. N., Hunter, K., Kanakidou, M., Kubilay, N., Prospero, J. M., Sarin, M., Surapipith, V., Uematsu, M., and Zhu, T.: Impacts of atmospheric nutrient deposition on marine productivity: roles of nitrogen, phosphorus, and iron, Global Biogeochem. Cy., 25, 1-10, 2011.

Paerl, H. W. and Whitall, D. R.: Anthropogenically-derived atmospheric nitrogen deposition, marine eutrophication and harmful algal bloom expansion: is there a link?, Ambio, 28, 307-311, 1999.

Pennington, J. T., Mahoney, K. L., Kuwahara, V. S., Kolber, D. D., Calienes, R., and Chavez, F. P.: Primary production in the eastern tropical Pacific: A review, Prog. Oceanogr., 69, 285-317, 2006.

Reay, D. S., Dentener, F., Smith, P., Grace, J., and Feely, R. A.: Global nitrogen depisition and carbon sinks, Nat. Geosci., 1, 430-437, 2008.

Schmittner, A., Oschlies, A., Matthews, H. D., and Galbraith, E. D.: Future changes in climate, ocean circulation, ecosystems, and biogeochemical cycling simulated for a business-as-usual $\mathrm{CO}_{2}$ emission scenario until year $4000 \mathrm{AD}$, Global Biogeochem. Cy., 22, GB1013, doi:10.1029/2007GB002953, 2008.

Seitzinger, S. P. and Kroeze, C.: Global distribution of nitrous oxide production and $\mathrm{N}$ inputs in freshwater and coastal marine ecosystems, Global Biogeochem. Cy., 12, 93-113, 1998.

Seitzinger, S. P. and Sanders, R. W.: Atmospheric inputs of dissolved organic nitrogen stimulate estuarine bacteria and phytoplankton, Limnol. Oceanogr., 44, 721-730, 1999.

Slomp, C. P. and Van Cappellen, P.: The global marine phosphorus cycle: sensitivity to oceanic circulation, Biogeosciences, 4, 155171, doi:10.5194/bg-4-155-2007, 2007.

Somes, C. J., Schmittner, A., Galbraith ,E. D., Lehmann, M. F., Altabet, M. A., Montoya, J. P., Letelier, R. M., Mix, A. C., Bourbonnais, A., and Eby, M.: Simulating the global distribution of nitrogen isotopes in the ocean, Global Biogeochem. Cy., 24, GB4019, doi:10.1029/2009GB003767, 2010.
Somes, C. J., Oschlies, A., and Schmittner, A.: Isotopic constraints on the pre-industrial oceanic nitrogen budget, Biogeosciences, 10, 5889-5910, doi:10.5194/bg-10-5889-2013, 2013.

Su, B., Pahlow, M., Wagner, H., and Oschlies, A.: What prevents nitrogen depletion in the oxygen minimum zone of the eastern tropical South Pacific?, Biogeosciences, 12, 1113-1130, doi:10.5194/bg-12-1113-2015, 2015.

Tyrrell, T.: The relative influences of nitrogen and phosphorus on oceanic primary production, Nature, 400, 525-531, 1999.

Van Cappellen, P. and Ingall, E. D.: Benthic phosphorus regeneration, net primary production, and ocean anoxia: a model of the coupled marine biogeochemical cycles of carbon and phosphorus, Paleoceanography, 9, 677-692, 1994.

Van Mooy, B. A. S., Keil, R. G., and Devol, A. H.: Impact of suboxia on sinking particulate organic carbon: enhanced carbon flux and preferential degradation of amino acids via denitrification, Geochim. Cosmochim. Ac., 66, 457-467, 2002.

Vet, R., Artz, R. S., Carou, S., Shawa, M., Ro, C., Aas, W., Baker, A., Bowersox, V. C., Dentener, F., Galy-Lacaux, C., Hou, A., Pienaar, J., J., Gillett, R., Forti, M. C., Gromov, S., Hara, H., Khodzherm, T., Mahowald, N. M., Nickovic, S., Rao, P. S. P., and Rei, N. W.: IA global assessment of precipitation chemistry and deposition of sulfur, nitrogen, sea salt, base cations, organic acids, acidity and $\mathrm{pH}$, and phosphorus, Atmos. Environ., 93, 3-100, 2014.

Wallmann, K.: Feedbacks between oceanic redox states and marine productivity: a model perspective focused on benthic phosphorus cycling, Global Biogeochem. Cy., 17, 1-10, 2003.

Wallmann, K.: Phosphorus imbalance in the global Ocean, Global Biogeochem. Cy., 24, GB4030, doi:10.1029/2009GB003643, 2010.

Ward, B. B., Devol, A. H., Rich, J. J., Chang, B. X., Bulow, S. E., Naik, H., Pratihary, A., and Jayakumar, A.: Denitrification as the dominant nitrogen loss process in the Arabian Sea, Nature, 461, 78-81, 2009.

Warneck, P.: Chemistry of the Natural Atmosphere, vol. 71 of International Geophysics Series, Elsevier, New York, 1988.

Wise, M., Calvin, K., Thomson, A., Clarke, L., Bond-Lamberty, B. Sands, R., Smith, S. J., Janetos, A., and Edmonds, J.: Implications of limiting $\mathrm{CO}_{2}$ concentrations for land use and energy, Science, 324, 1183-1189, 2009.

Zamora, L. M., Landolfi, A., Oschlies, A., Hansell, D. A., Dietze, H., and Dentener, F.: Atmospheric deposition of nutrients and excess $\mathrm{N}$ formation in the North Atlantic, Biogeosciences, 7, 777-793, doi:10.5194/bg-7-777-2010, 2010.

Zamora, L. M., Prospero, J. M., and Hansell, D. A.: Organic nitrogen in aerosols and precipitation at Barbados and Miami: implications regarding sources, transport and deposition to the western subtropical North Atlantic, J. Geophys. Res., 116, D20309, doi:10.1029/2011JD015660, 2011. 